\title{
Does epilepsy in multiplex autism pedigrees define a different subgroup in terms of clinical characteristics and genetic risk?
}

Claire Amiet ${ }^{1,2}$, Isabelle Gourfinkel-An ${ }^{3,4}$, Claudine Laurent ${ }^{1,5}$, Nicolas Bodeau', Bérengère Génin ${ }^{2}$, Eric Leguern ${ }^{3,4}$, Sylvie Tordjman ${ }^{6}$ and David Cohen ${ }^{1,7^{*}}$

\begin{abstract}
Background: Autism spectrum disorders (ASD) and epilepsy frequently occur together. Prevalence rates are variable, and have been attributed to age, gender, comorbidity, subtype of pervasive developmental disorder (PDD) and risk factors. Recent studies have suggested disparate clinical and genetic settings depending on simplex or multiplex autism. The aim of this study was to assess: 1) the prevalence of epilepsy in multiplex autism and its association with genetic and non-genetic risk factors of major effect, intellectual disability and gender; and 2) whether autism and epilepsy cosegregate within multiplex autism families.

Methods: We extracted from the Autism Genetic Resource Exchange (AGRE) database ( $n=3,818$ children from 1,264 families) all families with relevant medical data ( $\mathrm{n}=664$ children from 290 families). The sample included 478 children with ASD and 186 siblings without ASD. We analyzed the following variables: seizures, genetic and non-genetic risk factors, gender, and cognitive functioning as assessed by Raven's Colored Progressive Matrices (RCPM) and Vineland Adaptive Behavior Scales (VABS).

Results: The prevalence of epilepsy was $12.8 \%$ in cases with ASD and $2.2 \%$ in siblings without ASD $\left(P<10^{-5}\right)$. With each RCPM or VABS measure, the risk of epilepsy in multiplex autism was significantly associated with intellectual disability, but not with gender. Identified risk factors (genetic or non-genetic) of autism tended to be significantly associated with epilepsy $(P=0.052)$. When children with prematurity, pre- or perinatal insult, or cerebral palsy were excluded, a genetic risk factor was reported for 6/59 (10.2\%) of children with epilepsy and 12/395 (3.0\%) of children without epilepsy $(P=0.002)$. Finally, using a permutation test, there was significant evidence that the epilepsy phenotype co-segregated within families $\left(P<10^{-4}\right)$.
\end{abstract}

Conclusions: Epilepsy in multiplex autism may define a different subgroup in terms of clinical characteristics and genetic risk.

Keywords: Autism, Multiplex pedigree, Epilepsy, Intellectual disability

\section{Background}

Autism spectrum disorders (ASD) and epilepsy frequently occur together. Approximately $5 \%$ to $40 \%$ of individuals with autism have epilepsy [1], whereas the prevalence of epilepsy in the general population is about

\footnotetext{
* Correspondence: david.cohen@psl.aphp.fr

'Department of Child and Adolescent Psychiatry, Assistance

Publique-Hôpitaux de Paris (AP-HP), Groupe Hospitalier Pitié-Salpêtrière, Université Pierre et Marie Curie, 47 bd de l'Hôpital, 75013 Paris, France ${ }^{7}$ Institut des Systèmes Intelligents et Robotiques (ISIR), CNRS UMR 7222, Université Pierre et Marie Curie, 1 place Jussieu, 75005 Paris, France Full list of author information is available at the end of the article
}

$0.5 \%$ to $1 \%$. Conversely, $5 \%$ to $30 \%$ of individuals with epilepsy have ASD [2-5], whereas the prevalence of ASD in the general population is about $1 / 150$; although recent studies reached even higher rates: $1 / 80$ [6]. The variability of prevalence rates have been attributed to the heterogeneity of samples with respect to age, gender, comorbidity, subtype of ASD, intellectual disability and risk factors $[7,8]$. It may also result from the criteria used to diagnose epilepsy. Finally, the genetic background of autism may have a considerable impact on epilepsy rates in autism. 
Recently, a meta-analysis of 24 reports on autism and epilepsy confirmed intellectual disability and female gender as major risk factors of epilepsy in autism [9]. The pooled prevalence of epilepsy was $21.4 \%$ in individuals with autism and intellectual disability versus $8 \%$ in individuals with autism without intellectual disability, and the more severe the intellectual disability, the more prevalent the epilepsy. With a male:female ratio of 2, the risk of epilepsy was found significantly higher for females [9]. However, this might reflect the known circumstance that females with autism tend to be more severely mentally disabled [10].

Autism and epilepsy are both complex and heterogeneous disorders. Recent literature reviews underline the important role of genetic factors in the etiology of ASD [11-13]. Rare chromosomal abnormalities (for example maternally inherited duplications of chromosome 15q11-q13) and single gene syndromes (for example fragile $X$, tuberous sclerosis) are important risk factors of ASD. More recently, individual genes of major effect have been identified by resequencing or array-based methods, but variants at these and other loci are present in no more than $1 \%$ to $2 \%$ of children with ASD [14]. Some of these genes with major effects have been associated with ASD, intellectual disability and/or seizures, suggesting that the three disorders may share common genetic risk factors (Table 1). Recent whole genome DNA microarray studies have identified submicroscopic duplications and deletions (copy number variations (CNVs) located in many loci and mostly including de novo events) in the same developmental disorders (ASD, intellectual disability, epilepsy), and in schizophrenia as well [15-17] (Table 2).

However, all together, an identified genetic etiology is estimated to account for $10 \%$ to $20 \%$ of ASD cases [15]. Therefore, in the majority of epilepsy cases, most autism appears to be a multifactorial hereditary disorder, depending on polygenic heredity and environmental factors Environmental factors associated with autism are mainly pre-, peri- and postnatal, such as in utero exposure to teratogenic medications (for example thalidomide, valproate) [121], prematurity, neonatal encephalopathy and hyperbilirubinemia [122].

Most of the samples studied in autism are composed of autistic individuals without information about whether autism affects only one individual in the family (simplex autism) or multiple siblings in the family (multiplex autism). This is a major issue since higher genetic risk may be hypothesized in multiplex autism. Some recent studies have suggested disparate clinical and genetic settings depending on simplex or multiplex autism. More de novo rare mutations in genes of major effect have been associated with simplex autism [108], while an interactive effect of multiple common susceptibility alleles have long been hypothesized as risk factors of familial autistic syndromes $[123,124]$. Whether some clinical variables may help to delineate more homogeneous subgroups in multiplex autism remains an open question. Regarding epilepsy and ASD, only one study specified that part of the sample included individuals with multiplex autism [125]. However, there was no separate analysis of these two groups except to observe that a similar incidence of electroencephalogram (EEG) abnormalities was found. Banach et al. examined gender differences and intellectual quotients (IQs), and found no difference in non-verbal IQ between females and males in multiplex families, while females had lower non-verbal IQ scores than males in simplex families [126]. However, the prevalence of major effect genetic risk factors as a function of epilepsy, intellectual disability and gender in multiplex families remains unknown.

The aims of the current study are: 1) to assess the prevalence of seizures in multiplex autism and compare it to the prevalence of siblings without ASD. Since autism and epilepsy share common genetic risk factors, we hypothesize a higher risk of epilepsy in individuals with autism than siblings without ASD; 2) to compare the prevalence of major effect genetic risk factors in multiplex autism with and without epilepsy. We hypothesize the group with epilepsy to have an increased risk; 3 ) to assess whether autism and epilepsy co-segregate within multiplex autism families; and 4) to assess whether higher prevalence of epilepsy in multiplex autism is mediated by intellectual disability and gender as it has been shown in the literature [9].

\section{Methods}

Participants

Data were ascertained from all families participating in the Autism Genetic Resource Exchange (AGRE) in September 2011. Families with two or more members diagnosed with autism, pervasive developmental disorder-not otherwise specified (PDD-NOS) or Asperger syndrome may enroll in the AGRE program. Families register to the program then AGRE recruitment staff follow-up with families to confirm eligibility and complete the intake process. Families were excluded from the AGRE program if they had participated in another genetic study, a confirmed neurogenetic disorder, a pre- or perinatal injury, prematurity defined as delivery before 35 weeks of gestational age for single births or before 33 weeks of gestational age for twin births, a known chromosomal abnormality, or an abnormal neurological examination.

The diagnosis of autism was made using the standard Autism Diagnostic Interview-Revised (ADI-R) [127] with three affected status categories based on ADI-R results: autism, not quite autism (NQA) and broad spectrum. In the current report, we fused the last two categories as 
Table 1 Genes implicated in autism, epilepsy and/or intellectual disability

\begin{tabular}{|c|c|c|c|c|c|c|}
\hline Gene & Locus & Mutation & Transmission & Phenotype & Protein & Reference(s) \\
\hline \multirow[t]{2}{*}{$\overline{S C N 1 A}$} & $2 q 24$ & Point mutation & De novo & $\mathrm{ASD}, \mathrm{E}, \mathrm{ID}$ & $\mathrm{Na}_{\mathrm{v}} 1.1\left(\mathrm{Na}^{+}\right.$channel) & $\begin{array}{l}18-20] \\
\end{array}$ \\
\hline & & Deletion & Dominant inheritance & & & \\
\hline \multirow[t]{2}{*}{ SCN2A } & $2 q 23-q 24.3$ & Deletion & De novo & ASD, E, ID & $\mathrm{Na}_{\mathrm{v}} 1.2\left(\mathrm{Na}^{+}\right.$channel $)$ & {$[20-22]$} \\
\hline & & Point mutation & Inherited & & & \\
\hline SCN3A & $2 q 24$ & Deletion & De novo & $E, I D$ & $\mathrm{Na}_{\mathrm{v}} 1.3\left(\mathrm{Na}^{+}\right.$channel $)$ & {$[23,24]$} \\
\hline SCNIB & $19 q 13.1$ & Point mutation & Dominant inheritance & E & $\beta_{1}$ subunit $\left(\mathrm{Na}^{+}\right.$channel) & {$[25]$} \\
\hline KCNA1 & $12 \mathrm{p} 13$ & Point mutation & Dominant inheritance & $E, I D$ & $K_{v} 1.1\left(K^{+}\right.$channel) & {$[26,27]$} \\
\hline \multirow[t]{2}{*}{ KCNQ2 } & $20 q 13.3$ & Point mutation & Dominant inheritance & $E, I D$ & $\mathrm{~K}_{\mathrm{V}} 7.2\left(\mathrm{~K}^{+}\right.$channel $)$ & {$[28,29]$} \\
\hline & & Deletion & De novo & & & \\
\hline KCNQ3 & $8 q 24$ & Point mutation & Not known & E & $\mathrm{K}_{\mathrm{V}} 7.3\left(\mathrm{~K}^{+}\right.$channel) & {$[30]$} \\
\hline \multirow[t]{2}{*}{ KCNMA1 } & $10 q 22$ & Point mutation & Dominant inheritance & $A S D, E, I D$ & $\mathrm{~K}_{\mathrm{Ca}} 1.1\left(\mathrm{~K}^{+}\right.$channel) & {$[31,32]$} \\
\hline & & & De novo & & & \\
\hline \multirow[t]{2}{*}{ CACNATA } & 19 p13 & Point mutation & De novo & $E, I D$ & Cav2.1 (Ca ${ }^{2+}$ channel) & [33] \\
\hline & & & Dominant inheritance & & & \\
\hline GABRA1 & $5 q 34-q 35$ & Point mutation & Dominant inheritance & E & $\mathrm{A}_{1}$ subunit $\left(\mathrm{GABA}_{\mathrm{A}}\right.$ receptor) & [34] \\
\hline GABRG2 & $5 q 34$ & Point mutation & Dominant inheritance & $E, I D$ & Y subunit (GABA $A_{A}$ receptor) & {$[35,36]$} \\
\hline CHRNA2 & $8 p 21$ & Point mutation & Dominant inheritance & E & $a_{2}$ subunit (nACh receptor) & {$[37]$} \\
\hline \multirow[t]{2}{*}{ CHRNA4 } & $20 q 13.2-q 13.3$ & Point mutation & Dominant inheritance & $E, I D$ & $a_{4}$ subunit (nACh receptor) & {$[38,39]$} \\
\hline & & & De novo & & & \\
\hline \multirow[t]{2}{*}{ CHRNB2 } & $1 q 21$ & Point mutation & Dominant inheritance & $E$ & $\beta_{2}$ subunit (nACh receptor) & [40] \\
\hline & & & De novo & & & \\
\hline NLGN3 & Xq13.1 & Point mutation & Inherited & ASD & Inhibitory synapse formation & [41] \\
\hline \multirow[t]{2}{*}{ NLGN4 } & Xp22.31 & Point mutation & Inherited & ASD, ID & Synapse formation & {$[41,42]$} \\
\hline & & Deletion & & & & \\
\hline $\mathrm{CDH} 8$ & $16 q 21$ & Deletion & Inherited & ASD & Synapse formation & [43] \\
\hline PCDH10 & $4 q 28.3$ & Deletion & Inherited & ASD & Synapse formation & [44] \\
\hline \multirow[t]{2}{*}{ PCDH19 } & $\mathrm{Xq} 22$ & Deletion & De novo & $E, I D$ & Synapse formation & {$[45]$} \\
\hline & & Point mutation & Inherited & & & \\
\hline \multirow[t]{2}{*}{ NRXN1 } & $2 \mathrm{p} 16.3$ & Deletion & Recessive inheritance & $A S D, E, I D, S C Z$ & Synapse formation & {$[46-48]$} \\
\hline & & Point mutation & De novo & & & \\
\hline \multirow[t]{2}{*}{ CNTNAP2 } & $7 q 35$ & Deletion & Recessive inheritance & ASD, E, ID, SCZ & Synapse formation & [49-51] \\
\hline & & Point mutation & De novo & & & \\
\hline \multirow[t]{2}{*}{ SHANK2 } & $11 q 13.4$ & Deletion & De novo & ASD, ID & Synapse scaffolding & {$[52]$} \\
\hline & & Point mutation & Inherited & & & \\
\hline \multirow[t]{2}{*}{ SHANK3 } & $22 q 13.3$ & Deletion & De novo & ASD, ID, SCZ & Synapse scaffolding & {$[53,54]$} \\
\hline & & Point mutation & Inherited & & & \\
\hline \multirow[t]{2}{*}{ SYNGAP1 } & $6 p 21.3$ & Point mutation & De novo & $A S D, E, I D$ & Synapse RasGAP & {$[55,56]$} \\
\hline & & Deletion & Inherited, de novo & & & \\
\hline \multirow[t]{2}{*}{ CDKL5 } & Xp22 & Point mutation & De novo & $E, I D$ & Cyclin-dependent kinase-like 5 & {$[57,58]$} \\
\hline & & Deletion & Inherited & & & \\
\hline \multirow[t]{2}{*}{$A R X$} & Xp22.13 & Duplication & Inherited & ASD, E, ID & Aristaless-related homeobox protein & {$[59,60]$} \\
\hline & & & De novo & & & \\
\hline ATP1A2 & $1 q 21-23$ & Point mutation & Dominant inheritance & $E, I D$ & Sodium-potassium ATPase & {$[61,62]$} \\
\hline
\end{tabular}


Table 1 Genes implicated in autism, epilepsy and/or intellectual disability (Continued)

\begin{tabular}{llllll}
\hline SLC2A1 & 1p35-p31.1 & Deletion & Dominant inheritance & E, ID & GLUT1 \\
& & Point mutation & De novo & \\
& & Recessive inheritance & & \\
& & Point mutation & Inherited & E, ID & Syntaxin-binding protein \\
STXBP1 & $9 \mathrm{q} 34.1$ & De novo & & \\
& & & & \\
& & &
\end{tabular}

Adapted from Betancur [15] and Amiet [65]. ASD, autism spectrum disorders; E, epilepsy; GABA, $\gamma$-aminobutyric acid; GLUT1, glucose transporter type 1; ID, intellectual disability; nACh, nicotinic acetylcholine; RasGAP, Ras GTPase activating protein; SCZ, schizophrenia.

PDD-NOS. To meet the criteria for autism, the individual must exceed the ADI-R cutoff for autism in all domains. Children meeting the following criteria were classified as PDD-NOS: 1a) must meet cutoff scores for autism on the three core domains (social, communication, behavior) but not on the age of onset domain, or 1b) must be no more than one point below the cutoff score on any of the three core domains, while also meeting the cutoff for the age of onset domain; and 2) must meet one or more of the following: a) show a severe deficit in at least one domain, b) show more moderate deficits in at least two domains, and/or c) show only minimal deficits in all three domains.

The AGRE database consisted of 3,819 children from 1,264 families. We excluded the 3,150 children $(1,837$ children with autistic disorder, 226 children with PDDNOS and 1,087 children without autism) whose clinical data gave no information about the presence or absence of epileptic seizure. We excluded five more individuals who were reported by their family with a diagnosis of Asperger syndrome without any ADI-R available. We included the 664 children from 290 families (417 children with autistic disorder, 61 children with PDD-NOS and 186 children without autism) whose characteristics are discussed below. We found no significant differences between excluded and included individuals for age at ADI-R clinical assessment (mean $( \pm$ SD) $)$ (8.5 years $( \pm 4.9)$ versus 8.1 years $( \pm 4.7)$, respectively; $P=0.098)$, gender $(68.1 \%$ versus $69.7 \%$ of boys, respectively; $P=0.43)$ and Raven's nonverbal IQ $(100.2$ ( \pm 19.3$)$ versus 99.8 ( \pm 18$)$, respectively; $P=0.76$ ). We found a significant difference in the percentage of autistic disorder, PDD-NOS and unaffected children $(P=0.002)$, but the difference accounted for a higher percentage of unaffected children in the excluded sample (34.6\% versus $28.0 \%)$. In contrast with Raven's nonverbal IQ, we found a significant difference for Vineland composite standard score (62.6 $( \pm$ 21.6) versus 54.4 $( \pm 20.4)$, respectively; $\left.P<10^{-10}\right)$.

\section{Measures \\ Data relevant to epilepsy}

Most of the AGRE families had an extensive evaluation by pediatricians, psychiatrists and/or neurodevelopmental specialists in order to obtain medical and family history information. Data relevant to epilepsy were extracted from probands, and unaffected children's medical history files were provided by the AGRE database. These data were collected through a standardized method by AGRE and consist of the occurrence or not of afebrile seizures or remote febrile seizures, the age of onset, and the number of seizures and their type. After extraction from the AGRE database, data were reviewed by a neurologist and three groups were formed: epilepsy, remote febrile seizures (meaning febrile seizures with an identified antecedent classified as a risk factor for epilepsy) and only one

Table 2 Copy number variations (CNVs) associated with autism spectrum disorders (ASD), epilepsy, intellectual disability and schizophrenia

\begin{tabular}{lllll}
\hline Cytoband & Maximum coordinates & Phenotype & Deletion/duplication & References \\
\hline 1 q21.1 & $144.9-146.2$ & ASD, E, ID, SCZ & Deletion/duplication & {$[16,66-75]$} \\
$3 q 29$ & $197.1-198.9$ & ASD, E, ID, SCZ & Deletion/duplication & {$[16,74-81]$} \\
$7 q 11.23$ & $71.9-74.2$ & ASD, E, ID, SCZ & Deletion/duplication & {$[69,75,82-89]$} \\
$15 q 11.2-13.1$ & $21.1-26.2$ & ASD, E, ID, SCZ & Duplication & {$[68,69,72,83,90,91]$} \\
$15 q 13.3$ & $28.2-30.7$ & ASD, E, ID, SCZ & Deletion/duplication & {$[16,68-72,75,83,92-100]$} \\
$16 p 11.2$ & $29.4-30.1$ & ASD, E, ID, SCZ & Duplication & {$[16,68,74,75,83,101-107]$} \\
$16 p 11.2$ & $29.4-30.1$ & ASD, E, ID & Deletion & {$[68,83,92,101,102,104-110]$} \\
$16 p 13.11$ & $14.6-18.7$ & ASD, E, ID, SCZ & Deletion/duplication & {$[68,69,72,73,81,90,92,111-114]$} \\
$17 q 12$ & $31.5-33.1$ & ASD, E, ID, SCZ & Deletion/duplication & {$[73,81,115-117]$} \\
$22 q 11.2$ & $16.9-20.6$ & ASD, E, ID, SCZ & Deletion & {$[16,68,69,71,72,80,92,101,118,119]$} \\
\hline
\end{tabular}

Adapted from Betancur [15], Johnson and Shorvon [17], and Levinson et al. [120]. ASD, autism spectrum disorders; CNV, copy number variation; E, epilepsy; ID, intellectual disability; SCZ, schizophrenia. 
seizure. Epilepsy was defined as two or more afebrile seizures.

\section{Genetic and non-genetic risk factors of autism}

For each of the 478 included individuals with ASD, we determined whether there were known genetic and nongenetic risk factors of autism. Despite the exclusionary criteria described above, the database flags: 1) possible syndromic autism based on clinical (significant dysmorphology, abnormal neurologic exams) and morphologic criteria (abnormal imaging or medical tests); and 2) pre- or perinatal injuries and prematurity (defined as delivery before 35 weeks of gestational age for single births and before 33 weeks of gestational age for twin births). Also noted were: comorbid medical or psychiatric disorders and genetic abnormalities identified by clinical genetic investigation [128]. Most of the families of the AGRE dataset were screened for fragile $X$ syndrome using PCR technique. About half of the AGRE families had been karyotyped, and $228(47.7 \%)$ were analyzed for small nuclear ribonucleoprotein polypeptide N (SNRPN) duplication at 15q12 and 393 for telomere analyses for smallscale deletions and duplications. A sample of 943 families was genotyped using the HumanHap550 BeadChip (Illumina, San Diego, CA, USA) [129] and a sample of 777 families was genotyped using the 5.0 Chip (Affymetrix, Santa Clara, CA, USA) [130]. The details of these screenings are available on the AGRE website (http://www.agre.org).

Of the 664 children included in this analysis, 35 (5.3\%) children from 33 families (31 children with autistic disorder, two children with PDD-NOS and two children without autism) were flagged as having strong risk factors for both autism and seizures: pre- or perinatal insult, prematurity before 35 weeks of gestational age (19 children), chromosomal abnormality (eight children with a known trisomy, translocation or inversion, and one child with significant dysmorphology), or an abnormal neurological or cerebral imaging examination (seven children). We found no significant differences between these children and their siblings and the children with no flag for age on ADI-R clinical assessment $(P=024)$, gender $(P=0.42)$, mean Raven's non-verbal IQ $(P=0.17)$, mean Vineland composite standard score $(P=0.80)$, or the percentage of autistic disorder, PDD-NOS and unaffected children $(P=0.17)$.

\section{Raven's Colored Progressive Matrices (RCPM)}

Non-verbal intellectual capacity was measured by Raven's Colored Progressive Matrices (RCPM) [131]. The RCPM is a standardized test designed to measure non-verbal intellectual capacity in children from the age of 5 years. Scores on the RCPM correlate highly with scores on tests of general intellectual capacity [132]. The RCPM consist of 36 items, presented in three sets of 12 , which become progressively more difficult. Each item contains a pattern problem with one part removed and six pictured potential inserts, one of which contains the correct pattern. The number of correct answers is transformed to a non-verbal IQ score based on age-dependent normative data.

\section{Vineland Adaptive Behavior Scales (VABS)}

The adaptive functioning level was assessed by the Vineland Adaptive Behaviors Scales (VABS). The VABS is a semistructured parental interview that evaluates adaptive functioning in four domains: communication, daily living skills, socialization and motor skills. Age equivalent scores and standard scores are provided for each domain. Scores across domains can be combined to create an overall adaptive behavior composite standard score. Depending on the time of inclusion in AGRE, one of the two forms of the VABS was used: the survey form [133] and the second edition of the VABS (Vineland II) [134]. For the purposes of the current study, the overall adaptive behavior composite standard score was used.

\section{Statistical analysis}

$\mathrm{R}$ software, version 2.12.2, was used for the statistical analysis. First, we compared affected individuals with individuals without epilepsy. Fisher's exact test was used for analysis of the association between the qualitative variables. A Student's $t$-test was used for the analysis of the association between the quantitative variables and the group variables. Second, we tested whether epilepsy cosegregated within families. To do so, from the 290 families, we first extracted the 179 families in which pairs of two affected siblings had a complete dataset for epilepsy, since permutation tests cannot be applied on missing data. Each sib-pair was designated either concordant or discordant for epilepsy status. In each of the 20,000 permutations, the individuals with epilepsy were randomly assigned among the 179 families, and the resulting number of concordant sib-pairs was recorded. The $P$ value is the fraction of permutation in which the number of concordant sib-pairs exceeded the number in the observed data. Third, admixture analysis was used to determine the best-fit model for the age at onset of seizure in ASD. Given the literature, we hypothesized a model with two subgroups, including one with seizure onset before the age of 5 years and another with seizure onset close to adolescence. Finally, a multivariate analysis (logistic regression) was performed to assess which variables contribute to the risk of seizures.

To assess whether the inclusion of the 35 children from 33 families who were flagged with strong risk factors for autism and seizures biased our results, we performed secondary analyses excluding all families with such children. These analyses were performed on 586 children from 257 families who had medical data about presence or 
absence of epilepsy: 362 (61.8\%) children with autistic disorder, 53 (9\%) children with PDD-NOS and 171 (29.2\%) children without autism.

\section{Results}

Primary analyses were performed on 664 children from 290 families who had informative data about presence or absence of epilepsy: 417 (62.8\%) children with autistic disorder, 61 (9.2\%) children with PDD-NOS and 186 (28\%) children without autism (Table 3). Secondary analyses were performed on 586 children from 257 families after exclusion of children with strong risk factors for autism and seizures.

\section{Prevalence and type of epilepsy}

The prevalence of epilepsy was $13.4 \%$ (56/417) among cases with an autistic disorder, 8.2\% (5/61) among cases with PDD-NOS and 2.2\% (4/186) among siblings without autism $\left(P<10^{-4}\right)$. The risk of epilepsy was sevenfold higher for children with ASD (autistic disorder or PDD-NOS) when compared with their siblings without ASD (odds ratio $(\mathrm{OR})=0.15 ; 95 \%$ confidence interval $(\mathrm{CI}): 0$ to 0.4 ; $\left.P<10^{-5}\right)$. The prevalence of remote febrile seizures was $4.6 \%(22 / 478)$ in cases with an ASD and 2.7\% (5/186) in siblings without ASD (OR $=1.75$; $95 \% \mathrm{CI}$ : 0.63 to 5.99 ; $P=0.38)$. The prevalence of one afebrile seizure was $14 / 478(2.9 \%)$ in cases with an ASD and $0.5 \%(1 / 186)$ in siblings without ASD (OR $=5.57$; 95\% CI: 0.84 to 237.1 ; $P=0.08)$. Secondary analyses excluding children with strong risk factors for autism and seizures yielded similar results: the prevalence of epilepsy was $12.2 \%(44 / 362)$ in cases with an autistic disorder, 5.7\% (3/53) in cases with PDD-NOS and $2.3 \%(4 / 171)$ in siblings without autism $(P=0.0002)$.

The mean age of children with ASD was 9.2 years $( \pm 5.0)$ at the time of their clinical assessment. Children with ASD and epilepsy were significantly older (mean age: 12.8 years \pm 8.6$)$ than children with ASD without epilepsy (mean age: 8.7 years \pm 4.0$)\left(P<10^{-8}\right)$. Mean age of the first seizure was 4.7 years $( \pm 3.8)$. Figure 1 summarizes the distribution of seizure onset according to age. Given the 4-year older age of children with epilepsy, the distribution of age of individuals with ASD without epilepsy, and of individuals with ASD and epilepsy, is also given. As several reports showed that there may be distinct ages at onset of subgroups among individuals with epilepsy, we conducted an admixture analysis to test whether the observed distribution for age at onset in individuals with ASD and seizure $(\mathrm{n}=55)$ was a mixture of Gaussian distributions. A parametric bootstrap with $\mathrm{B}=500$ replications of the likelihood ratio statistic was performed for testing the null hypothesis of a onecomponent fit versus the alternative hypothesis of a twocomponent fit. The result was significant $(P<0.001)$ and therefore the model with two components was adequate. The mean ages estimated in this model were 2.3 years $( \pm 1.3)$ and 8.3 years $( \pm 3.5)$ (Figure 2). All types of seizures were reported in children with autism and epilepsy $(n=61): 12 \quad(19.7 \%)$ children had generalized seizures, 17 (27.9\%) children had absences, 14 (23.0\%) children had complex partial seizures, 11 (18.0\%) children had multiple seizure types, and the type of seizure was unknown for seven (11.5\%) children.

Secondary analyses excluding children with strong risk factors for autism and seizures yielded similar results: mean age of ASD children $=9.1$ years $( \pm 4.7)$; mean age of ASD and epilepsy children $=12.4$ years $( \pm 7.0)$ versus mean age of ASD children without epilepsy $=8.7$ years $( \pm 4.1)\left(P<10^{-6}\right)$; mean age at the first seizures $=5.2$ years $( \pm 4.1)$; similar proportions of generalized seizures $(21.3 \%)$, absences (27.7\%), complex partial seizures (23.4\%), multiple seizures types (19.1\%), and unknown (8.5\%).

\section{Co-segregation analyses and prevalence of genetic and non-genetic risk factors as a function of epilepsy} Of the 478 children with ASD, 464 (97.1\%) children underwent genetic testing (karyotyping and/or array comparative genomic hybridization $(\mathrm{aCGH})$, and/or genomewide association (GWA)). A total of $42(8.8 \%)$ children had a known possible genetic or non-genetic risk factor for autism (39 children with autistic disorder, three children with PDD-NOS; Table 4). In decreasing frequency,

Table 3 Sample characteristics and prevalence of epilepsy according to clinical status

\begin{tabular}{|c|c|c|c|c|}
\hline Characteristics & Autistic disorder & PDD-NOS & Total (ASD) & Siblings without autism \\
\hline Total (n) & 417 & 61 & 478 & 186 \\
\hline Gender (male/female) & $334 / 83$ & $48 / 13$ & $382 / 96$ & $81 / 105$ \\
\hline Mean age (years) & $9.33( \pm 5.02)$ & $8.67( \pm 5.01)$ & $9.24( \pm 5.02)$ & $10.56( \pm 6.59)$ \\
\hline Epilepsy & $56(13.4 \%)$ & $5(8.2 \%)$ & $61(12.8 \%)$ & $4(2.2 \%)$ \\
\hline Remote febrile seizures & $16(3.8 \%)$ & $6(9.8 \%)$ & $22(4.6 \%)$ & $5(2.7 \%)$ \\
\hline One afebrile seizure & $14(3.4 \%)$ & $0(0 \%)$ & $14(2.9 \%)$ & $1(0.5 \%)$ \\
\hline Risk factors for ASD & $39(9.6 \%)$ & $3(5.4 \%)$ & $42(8.8 \%)$ & 0 \\
\hline Risk factors for ASD and comorbid seizures & $10(2.5 \%)$ & 0 & $10(2.2 \%)$ & 0 \\
\hline
\end{tabular}

Performed on 664 children and 290 families. ASD, autism spectrum disorders; PDD-NOS, pervasive developmental disorder-not otherwise specified. 


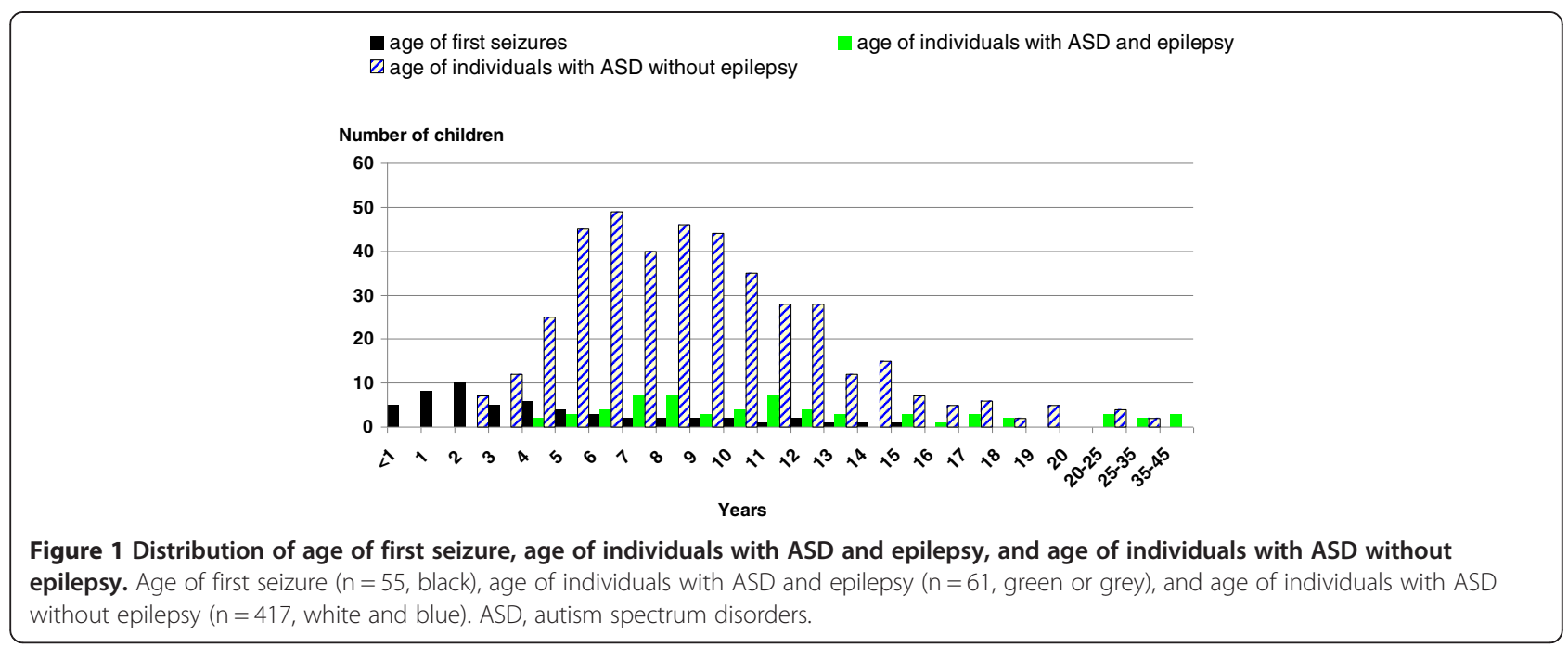

we found prematurity and/or pre- or perinatal insult $(\mathrm{n}=19)$, chromosomal abnormality $(\mathrm{n}=14)$, abnormal cerebral imaging or significant developmental abnormality $(\mathrm{n}=3)$, comorbid medical disease associated with ASD $(\mathrm{n}=4)$, and cerebral palsy $(\mathrm{n}=2)$. An epilepsy was reported for ten children (all had autistic disorder). Genetic or nongenetic risk factors of autism tended to be significantly associated with epilepsy (OR $=2.25 ; 95 \% \mathrm{CI}$ : 0.93 to 5.04; $P=0.052$ ). When children with prematurity, pre- or

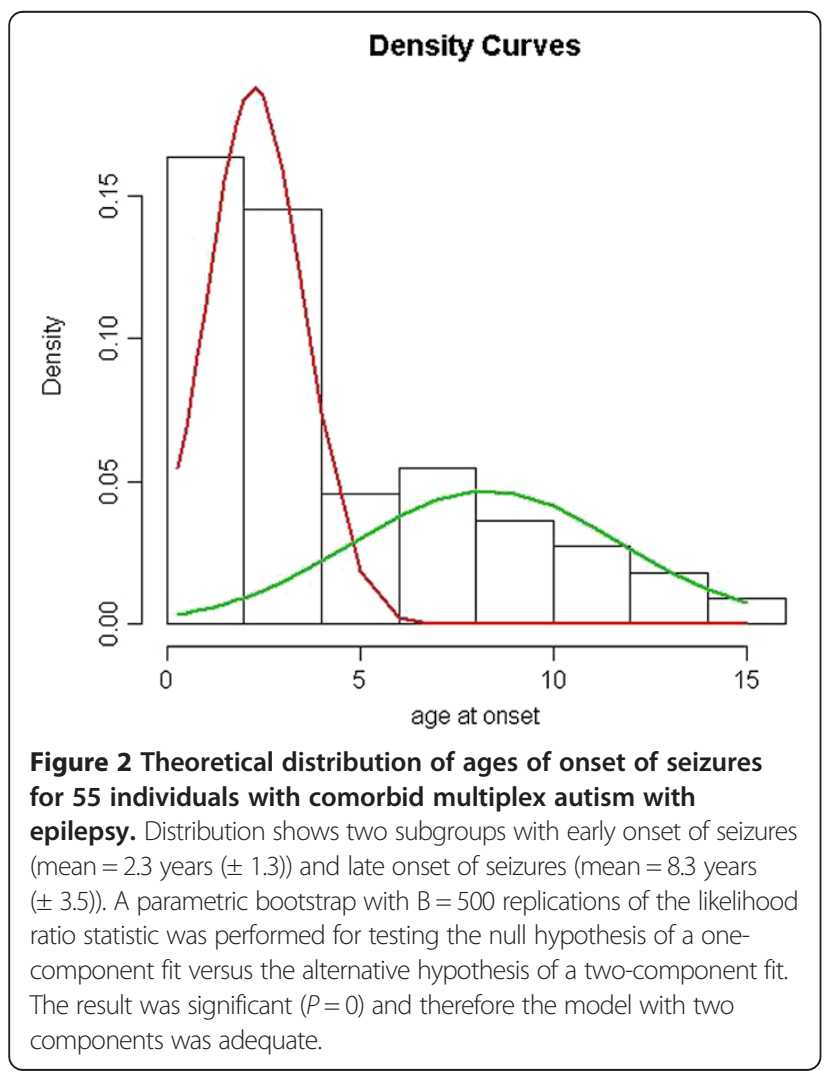

perinatal insult, or cerebral palsy were excluded, a known or possible genetic risk factor was reported for $10.2 \%(6 / 59)$ of children with epilepsy and 3.0\% (12/395) of children without epilepsy ( $\mathrm{OR}=3.6$; $95 \% \mathrm{CI}$ : 1.06 to $10.9 ; P=0.02)$.

Finally, there was significant evidence that epilepsy cosegregated within autism sib-pairs. Indeed, among the 179 families with sib-pairs affected by ASD, we found 154 sib-pairs concordant (meaning both siblings with ASD had epilepsy or did not have epilepsy) for associated epilepsy, while 25 sib-pairs were discordant (permutation: $\left.P<10^{-4}\right)$. Secondary analyses excluding children with strong risk factors for autism and seizures yielded similar results: among the 155 families with sib-pairs affected by ASD, we found 132 sib-pairs concordant for associated epilepsy, while 23 sib-pairs were discordant (permutation test: $P=0.0049$ ). Table 5 details the 11 AGRE families with two children with ASD and comorbid epilepsy, showing clinical status, type of seizure and known risk factors in all siblings.

\section{Epilepsy and non-verbal IQ/adaptive level}

Given the heterogeneity of general cognitive function in ASD, we used two measures to assess whether epilepsy was associated with intellectual disability in multiplex autism. An assessment with the RCPM was applied to 438 children with ASD (381 children with an autistic disorder and 57 children with PDD-NOS). One hundred forty-three children were not testable and ten children scored above the highest possible age-specific nonverbal IQ, without numeric scores available. The mean non-verbal IQ of children with ASD $(\mathrm{n}=285)$ was 99.6 $( \pm$ 18.0). Stratification of cases into two categories: IQ $<70(\mathrm{n}=17)$ and IQ $\geq 70(\mathrm{n}=278)$ showed a fivefold increased risk of epilepsy for children with an IQ $<70$ $(7 / 17 ; 41.2 \%)$ comparing children with an IQ $\geq 70$ $(31 / 278 ; 11.2 \%)(\mathrm{OR}=5.5 ; 95 \%$ CI: 1.7 to $17.5 ; P=0.005)$. 
Table 4 Risk factors of autism in the AGRE sample according to epilepsy

\begin{tabular}{|c|c|c|c|}
\hline Risk factors & Total (n) & Epilepsy (n) & No epilepsy (n) \\
\hline Total of individuals & 478 & 63 & 415 \\
\hline Chromosomal abnormality or genetic condition & $14(2.92 \%)$ & $4(6.35 \%)$ & $10(2.4 \%)$ \\
\hline 16p11.2 deletion/duplication & 4 & 2 & 2 \\
\hline 15q11-13 duplication & 3 & 1 & 2 \\
\hline 22q11.21 duplication & 1 & 0 & 1 \\
\hline 22q13.33 duplication & 1 & 0 & 1 \\
\hline $\mathrm{t}(2 ; 9)(\mathrm{p} 13 ; \mathrm{q} 34.3)$ & 1 & 1 & 0 \\
\hline Mosaic t(3;16) & 1 & 0 & 1 \\
\hline Mosaic t $(3 ; 14)$ & 1 & 0 & 1 \\
\hline Trisomy 21 & 1 & 0 & 1 \\
\hline Mosaic trisomy 12 & 1 & 0 & 1 \\
\hline Prematurity ${ }^{a} /$ pre- or perinatal insult & 19 (3.98\%) & $3(4.76 \%)$ & $16(3.9 \%)$ \\
\hline Cerebral palsy & $2(0.42 \%)$ & 0 & $2(0.48 \%)$ \\
\hline Abnormal cerebral imaging & $3(0.63 \%)$ & $2(3.17 \%)$ & $1(0.24 \%)$ \\
\hline Agenesis of corpus callosum & 1 & 1 & 0 \\
\hline Left frontal damage & 1 & 1 & 0 \\
\hline Not given & 1 & 0 & 1 \\
\hline Other significant abnormality & $4(0.84 \%)$ & $1(1.59 \%)$ & $3(0.72 \%)$ \\
\hline Significant dysmorphology & 2 & 0 & 2 \\
\hline Mitochondrial disorder, mild tonsillectomy (premature puberty) & 1 & 1 & 0 \\
\hline Cranial nerve paralysis (congenital versus traumatic) & 1 & 0 & 1 \\
\hline Total of individuals with abnormalities ${ }^{\mathrm{b}}$ & $42(8.8 \%)$ & $10(15.9 \%)$ & $32(7.71 \%)$ \\
\hline
\end{tabular}

${ }^{a}$ Defined as delivery before 35 weeks of gestational age for single births or before 33 weeks of gestational age for twin births; ${ }^{b} P=0.052$. AGRE, Autism Genetic Resource Exchange.

An assessment with VABS was performed in 386 children with ASD (336 children with an autistic disorder and 50 children with PDD-NOS). The mean overall adaptive behavior composite standard score of children with ASD was 54.0 ( \pm 20.2). Stratification of cases into two categories: composite standard score $<70$ $(\mathrm{n}=294)$ and composite standard score $\geq 70 \quad(\mathrm{n}=92)$ showed a threefold increased risk of epilepsy for children with a composite standard score $<70(45 / 294$ (15.3\%)) comparing children with a composite standard score $\geq 70 \quad(5 / 92 \quad(5.4 \%) \quad(\mathrm{OR}=3.1 ; \quad 95 \% \quad \mathrm{CI}: 1.2$ to 10.5 ; $P=0.015)$. Figure 1 depicts the frequency of comorbid epilepsy in individuals with ASD as a function of composite standard score. The more severe the impairment of adaptive level, the more prevalent the epilepsy $(P=0.002)$.

\section{Epilepsy and gender}

Among the 96 females with a diagnosis of ASD (autistic disorder or PDD-NOS), $16.7 \%(n=16 / 96)$ had epilepsy. For the 382 males with ASD, 11.8\% (45/382) had epilepsy. The male:female ratio was 4.2 for the children with ASD without epilepsy, and 2.9 for the children with
ASD and with epilepsy. However, the difference was not statistically significant $(\mathrm{OR}=0.7 ; 95 \% \mathrm{CI}: 0.3$ to 1.3 ; $P=0.268$ ). Considering all the children with ASD regardless of their epileptic status, the male:female ratio was not significantly different when the sample was stratified into two groups (normal intelligence versus intellectual disability) based on the non-verbal IQ (RCPM: $\geq 70, \mathrm{n}=278 ;<70, \mathrm{n}=17$ ) (male:female ratio $=3.3$ versus 4.5 , respectively) (OR $=0.7 ; 95 \% \mathrm{CI}: 0.2$ to $3.2 ; P=0.788$ ) or the adaptive level (VABS: $\geq 70, \mathrm{n}=92 ;<70, \mathrm{n}=294$ ) (male:female ratio $=3.4$ versus 3.9 , respectively) $(\mathrm{OR}=1.2$; 95\% CI: 0.6 to $2.1 ; P=0.664$ ). Furthermore, there was no difference when the sample was stratified into four groups based on the adaptive level $(<40,40$ to 54,55 to $69, \geq 70$; $P=0.591)$.

\section{Multivariate analysis}

To confirm univariate variables associated with the risk of seizures, we used a logistic regression. ASD (estimate $=$ 2.49, $P=1.110^{-5}$; $\mathrm{OR}=12$; $95 \% \mathrm{CI}: 4.46$ to 43.1$)$, age (estimate $=0.11, P=1.1 \quad 10^{-6} ; \quad \mathrm{OR}=1.15 ; 95 \% \mathrm{CI}: 1.07$ to 1.17 ) and gender (male: estimate $=-0.61, P=0.049$; 
Table 5 AGRE families with two children with ASD and comorbid epilepsy $(n=11)$ : clinical status, type of seizures and risk factors in all siblings ${ }^{a}$

\begin{tabular}{|c|c|c|c|c|}
\hline Family & Gender & Autism diagnosis & Type of seizure $^{\mathrm{b}}$ & Risk factor of ASD and/or epilepsy \\
\hline \multirow[t]{3}{*}{ AU0025 } & M & Autism & Partial & Mitochondrial disorder, mild tonsillectomy (premature puberty) \\
\hline & M & Autism & Multiple & No risk reported \\
\hline & $\mathrm{F}$ & Unaffected & No seizure & Unknown \\
\hline \multirow[t]{2}{*}{ AU0051 } & M & Autism & Absence & No risk reported \\
\hline & M & Autism & Absence & Agenesis of corpus callosum \\
\hline \multirow[t]{3}{*}{ AU0123 } & $\mathrm{F}$ & Autism & Partial & Prematurity ${ }^{\complement} /$ pre- or perinatal insult \\
\hline & M & Autism & Multiple & Unknown \\
\hline & $\mathrm{F}$ & Unaffected & No seizure & Unknown \\
\hline \multirow[t]{4}{*}{ AU0176 } & $\mathrm{F}$ & Autism & Partial & No risk reported \\
\hline & M & Autism & Partial & No risk reported \\
\hline & M & Unaffected & No seizure & Unknown \\
\hline & $\mathrm{F}$ & Unaffected & No seizure & Unknown \\
\hline \multirow[t]{4}{*}{ AU0275 } & M & Autism & Multiple & No risk reported \\
\hline & M & Autism & Not indicated & Unknown \\
\hline & $\mathrm{F}$ & Unaffected & No seizure & Unknown \\
\hline & $\mathrm{F}$ & Unaffected & No seizure & Unknown \\
\hline \multirow[t]{2}{*}{ AU0461 } & M & Autism & Generalized & No risk reported \\
\hline & M & Autism & Generalized & Unknown \\
\hline \multirow[t]{3}{*}{ AU0548 } & $\mathrm{F}$ & Autism & Absence & No risk reported \\
\hline & M & Autism & Not indicated & No risk reported \\
\hline & $\mathrm{F}$ & Unaffected & No seizure & Unknown \\
\hline \multirow[t]{2}{*}{ AU0731 } & M & Autism & Generalized & Prematurity ${ }^{c} /$ pre- or perinatal insult \\
\hline & M & PDD-NOS & Not indicated & Unknown \\
\hline \multirow[t]{3}{*}{ AU0765 } & M & Autism & Absence & Unknown \\
\hline & $\mathrm{F}$ & PDD-NOS & Not indicated & $t(2 ; 9)(p 13 ; q 34.3)$ \\
\hline & M & Unaffected & No seizure & Unknown \\
\hline \multirow[t]{2}{*}{ AU0922 } & M & Autism & Partial & No risk reported \\
\hline & $\mathrm{F}$ & Autism & Partial & Unknown \\
\hline \multirow[t]{2}{*}{ AU1208 } & M & Autism & Multiple & 15q11-13 duplication \\
\hline & M & Autism & Absence & Unknown \\
\hline
\end{tabular}

${ }^{a}$ From the 154 families included in the co-segregation analysis, the families with ASD children and without epilepsy are not detailed in this table; ${ }^{b}$ not indicated means that the type of seizures was not given in the AGRE database, although the patient exhibits epilepsy; ${ }^{\mathrm{c}}$ defined as delivery before 35 weeks of gestational age for single births or before 33 weeks of gestational age for twin births. AGRE, Autism Genetic Resource Exchange; ASD, autism spectrum disorders; PDD-NOS, pervasive developmental disorder-not otherwise specified.

$\mathrm{OR}=0.54 ; 95 \% \mathrm{CI}: 0.3$ to 1.013$)$ were associated with the risk of seizure. In ASD individuals only, gender was not significantly associated, whereas age and intellectual disability were significantly associated, whether intellectual disability was measured with VABS (estimate $=1.15$, $P=0.02 ; \mathrm{OR}=3.2 ; 95 \% \mathrm{CI}: 1.3$ to 9.6$)$ or with RCPM (estimate $=1.57, P=0.005 ; \mathrm{OR}=4.85 ; 95 \% \mathrm{CI}$ : 1.53 to 14.56 ).

\section{Discussion}

Epilepsy in autism has been a subject of increasing interest, and reported prevalence rates of seizures in this condition vary from $5 \%$ to $40 \%$ [1]. The variability of rates have been attributed to the heterogeneity of samples with respect to age, gender, comorbidity, subtype of pervasive developmental disorder (PDD), intellectual disability and risk factors [9]. But most of the studies have been conducted in samples with simplex autism; for example the prevalence found in the Simons Simplex Collection (a large multisite phenotypic and DNA collection that includes families $(\mathrm{n}=2,644)$ in which there is only one child (aged 4 to 17 years) with ASD) is $2.4 \%$ [135]. In multiplex families, we found that $13.4 \%$ of children with autism and $8.2 \%$ of 
children with PDD-NOS had epilepsy. These results are in the range of prevalence rates described in the literature. In these multiplex families, we found that $2.2 \%$ of the siblings without autism had epilepsy. This prevalence rate is high compared to the general population where $0.7 \%$ to $0.8 \%$ of children up to the age of 15 years have repeated seizures [136]. Moreover, the permutation tests performed in this study show significant evidence that epilepsy phenotypes co-segregated within families.

Studies suggest that there are two peaks of onset of seizures in autism, one in early childhood (before the age of 5 years old), and one near adolescence [137]. In the sample studied here, the admixture analysis confirms this two-peak model: $62 \%$ of the children had their first seizures before the age of 5 years. Mean age of onset for the second peak is in pre/early adolescence as only $9 \%$ of the children had their first seizure after the age of 12 years. However, with a mean age of 9.2 years, the children studied are relatively young and many of them had not yet reached adolescence. Therefore, it is likely that our estimate of the age of onset for the later peak may be spuriously low as we cannot rule out that epilepsy could begin later for some individuals. Unfortunately, conducting a subanalysis with individuals aged 16 years and older was not possible given the sample size.

The risk of epilepsy in individuals with simplex autism was significantly associated with intellectual disability and gender. In a meta-analysis of 17 studies, the pooled prevalence of epilepsy was $21.5 \%$ in individuals with autism and intellectual disability, against $8 \%$ in individuals with autism and normal intelligence [9]. Of note, the increased risk with gender in simplex autism may reflect the known circumstance that females with autism tend to have more severe intellectual disability: the more severe the intellectual disability, the lower the male:female ratio [10]. In the present study, the respective prevalence rates of epilepsy was $41.2 \%$ in individuals with autism and intellectual disability, against $11.1 \%$ in individuals with autism and normal intelligence $(P=0.005)$, and the more the adaptive behavior level was impaired, the higher the prevalence of epilepsy (Figure 3). However, there was no increase of epilepsy linked to gender in individuals with ASD. Furthermore, no significant difference in IQ among males and females was found in the AGRE sample. A similar result was suggested in previous reports of multiplex families [126,138].

Identification or strong suspicion of a risk factor for autism (genetic or not) tended to increase the prevalence of epilepsy. The non-genetic risk factors identified were mainly perinatal fetal distress, the implication of which for autism, epilepsy and intellectual disability is well known. The prevalence of epilepsy remained significantly higher even when only identified or suspected genetic risk factors were considered. Genetic risk factors may be more often implicated when autism and epilepsy are associated [139]. This is also the case in multiplex families.
Interpretation of the informative families presented in Table 5 requires consideration of the AGRE database limitations, which include: excluding individuals with major perinatal risk factors or with known genetic abnormalities (for example fragile $\mathrm{X}$ syndrome) (but some siblings with such risk factors may have been included); and in many individuals, data are unknown or missing (for example not all individuals underwent $\mathrm{CNV}$ search; see Methods). Also, large family histories including epilepsy and ASD statuses of all members were not available. Careful scrutiny of Table 5 shows that several combinations of risk can lead to a multiplex pedigree: 1) the existence of a common risk factor for epilepsy and autism leading to the suggestion of screening for known genetic risk factors of epilepsy in AGRE families AU25, AU51, AU176, AU275, AU461, AU548 and AU922; and 2) the co-occurrence of two different risk factors (genetic and non-genetic ones) leading to a false 'multiplex pedigree', such as in families AU731, AU123, AU765 and AU1208; and 3) combinations of major and minor risk factors as it cannot be excluded that a) in some families interpretation of genotype/phenotype relationship may be particularly complex (for example AU25, AU51) and b) the same ASD genetic risk factor may be responsible for increased risk of prematurity (for example AU731).

In terms of pathophysiological mechanisms, several hypotheses have been proposed to explain the comorbidity between autism and epilepsy: 1) accidental co-occurrence given the high frequency of both conditions; 2) altered internal organization of minicolumns in the cortex of autistic individuals may be associated with a defect in inhibitory local circuit projection, and the defect in $\gamma$-aminobutyric acid (GABA)ergic fibers may correlate with the increased prevalence of seizures in autism $[140,141]$; 3) common genetic or neurodevelopmental risk factors; and 4) epilepsy by itself may induce the development of autistic symptoms [142]. Indeed, early-life seizures may affect synaptic plasticity through alteration of neurotransmitter receptor systems and molecules essential for intrinsic neuronal function, and changes that may contribute to an enhanced risk of autism [143,144]. Supporting this hypothesis, infantile spasms and/or early-onset seizures have been significantly associated with autism [145-147]. In the present study, few children had seizures in their first year of life $(11 / 63,17 \%)$ and none had infantile spasms. Thus, this mechanism may not account for much of the high prevalence found. As stated previously, in individuals with autism from multiplex families, common pathophysiological mechanisms appear to be more prevalent and may be genetic. If both autism and epilepsy can be considered as disorders of synaptic plasticity [143,144], autism and epilepsy may be the consequences of the same pathophysiological mechanisms, resulting in abnormal plasticity of genetic origin. Numerous genetic conditions that 


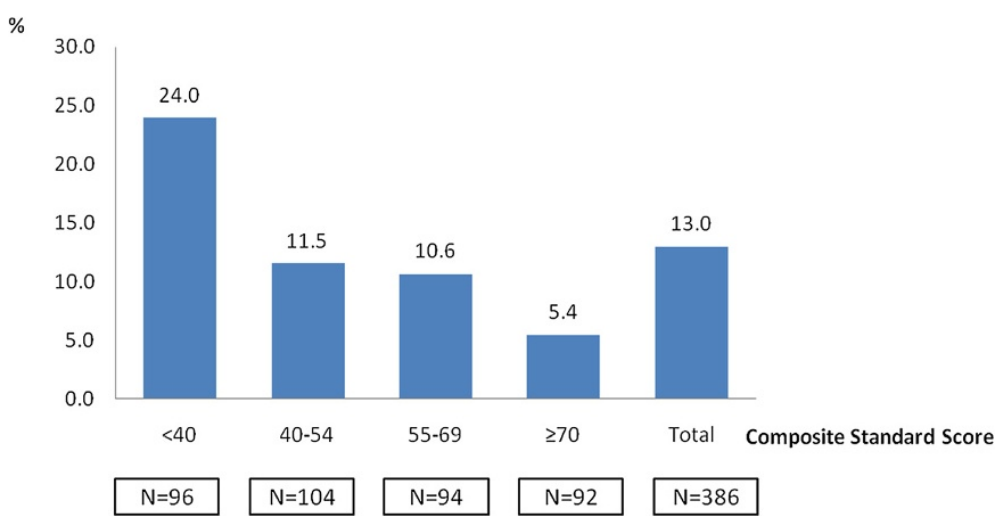

Figure 3 Frequencies of comorbid epilepsy in children $(n=386)$ with autism from multiplex families as function of the Vineland Adaptive Behavior Scales (VABS) composite standard score.

associate autism and epilepsy in their phenotypic features are caused by mutations in genes implicated in synaptic development, functioning and/or plasticity, such as Angelman syndrome [148], fragile X syndrome [149], Rett syndrome [150] and tuberous sclerosis [120,151]. Furthermore, missense and nonsense mutations of several genes involved in neurodevelopment have been identified in individuals with epilepsy, autism or both (Table 1). Most of those genes are involved in cerebral development pathways and functioning: synaptic formation (NLGN4, NRXN1, CDH8, PCDH19, SHANK3), ionic channel subunits (SCN1A, SCN2A, SCN1B, KCNMA1, KCNQ2, CACNA1A) and neurotransmitter receptors (GABRG2, CHRNA4). Similarly, CNVs such as 1q21.1, 3q29, 7q11.23, 15q11-13, 15q13.3, 16p11.2, 16p13.11, 17q12 and 22q11.2 have been implicated in different developmental disorders, such as ASD, intellectual disability and epilepsy $[15,17,152]$, as well as schizophrenia $[16,152,153]$ (Table 2). Autism, epilepsy and intellectual disability may share alteration of common pathways involved in neurodevelopmental maturation and neural functioning. We propose that these genes need to be more systematically investigated as major and minor risk factors.

Although the current study was conducted in the largest available sample of multiplex families, limitations should be listed. First, we cannot exclude biases in recruitment due to exclusion criteria as evidenced by the very low rate of infantile spasm in the sample. Furthermore, of the 664 children included in this analysis, 35 children (31 children with autistic disorder, two children with PDD-NOS and two children without autism) had strong risk factors for autism and seizures, such as pre- or perinatal insult/prematurity before 35 weeks $(n=19)$, chromosomal abnormality $(n=8)$, or abnormal neurological or brain imaging examination $(n=7)$. However, when analyses were performed excluding these children and their siblings, the results remained unchanged (see also Additional file 1). Second, individuals' ages were significantly different in children with autism with epilepsy, and children with autism without epilepsy, and the small number of adolescents may have reduced the prevalence of late onset seizures. Third, given the heterogeneity of intellectual functioning in autism and the heterogeneity of intellectual disability measures, we used two standardized tools for the cognitive and adaptive assessment: RCPM and VABS. Assessing a broad sample of 38 autistic children, Dawson et al. found scores on the RCPM to be, on average, 30 percentile points higher than their scores on the Wechsler scale of intelligence [154]. The VABS assess the adaptive functioning with a parent interview. Strong positive relationships have been found between Vineland composite and Vineland subscales (communication, socialization, daily living skills) and IQ, particularly when considering low functioning individuals [155]. Therefore, the two scales can be considered as complementary for the cognitive assessment of children with autism. The fact that we found similar results in the AGRE sample strengthens this view. Fourth, we cannot exclude that the absence of association with gender was related to our final sample size and a lack of statistical power. To assess this issue, we decided to perform a metaanalysis in a larger sample including other studies reporting IQ in multiplex pedigrees $[126,138]$. The standardized mean difference between mean non-verbal IQ in males versus females from multiplex pedigrees was 0.01 (95\% CI: -0.17 ; 0.19 ), meaning that there is no difference between mean non-verbal IQ according to gender (Additional file 2: Figure S1). The meta-analysis confirmed our results.

\section{Conclusion}

We conclude that epilepsy in multiplex autism may define a different subgroup in terms of clinical characteristics and genetic risk: association with intellectual disability, no association with gender and possible common risk factors. Future studies should be encouraged to increase knowledge of common genetic risk factors between ASD and epilepsy. 


\section{Additional files}

\section{Additional file 1: Secondary analyses.}

Additional file 2: Figure S1. Standardized mean difference between mean non-verbal IQ in males versus females from multiplex pedigrees: a meta-analysis of three multiplex autism pedigrees $(n=719)$.

\begin{abstract}
Abbreviations
aCGH: Array comparative genomic hybridization; ADI-R: Autism diagnostic interview-revised; AGRE: Autism genetic resource exchange; ASD: Autism spectrum disorders; Cl: Confidence interval; CNV: Copy number variation; EEG: Electroencephalogram; GABA: $\gamma$-aminobutyric acid; GLUT1: Glucose transporter type 1; GWA: Genome-wide association; ID: Intellectual disability; IQ: Intellectual quotient; nACh: Nicotinic acetylcholine; NQA: Not quite autism; OR: Odds ratio; PCR: Polymerase chain reaction; PDD: Pervasive developmental disorder; PDD-NOS: Pervasive developmental disorder-not otherwise specified; RasGAP: Ras GTPase activating protein; RCPM: Raven's colored progressive matrices; SCZ: Schizophrenia; SD: Standard deviation; SNRPN: Small nuclear ribonucleoprotein protein N; VABS: Vineland adaptive behavior scales.
\end{abstract}

\section{Competing interests}

CA and BG are salaried employees of IntegraGen (Évry, France). DC and ST are compensated consultants for IntegraGen. IGA, CL, EL and NB declare that they have no competing interests.

\section{Authors' contributions}

$C A, D C, C L, S T$ and EL designed the study. CA, BG and IGA extracted the data and performed the quality assessment. CA, IGA, EL and CL critically reviewed the literature. $\mathrm{NB}, \mathrm{BG}, \mathrm{CA}, \mathrm{CL}$ and $\mathrm{DC}$ performed the statistical analysis. NB, $C A$ and DC performed the meta-analysis. CA, CL, IGA and DC wrote a preliminary draft. All authors read, critically modified and approved the final manuscript.

\section{Acknowledgements}

We gratefully acknowledge the resources provided by the AGRE Consortium and the participating AGRE families. The AGRE is a program of Autism Speaks and is supported, in part, by grant 1U24MH081810 from the National Institute of Mental Health to Clara M Lajonchere (principal investigator). This work was supported by the Orange Foundation.

The AGRE Consortium comprises: Dan Geschwind MD PhD UCLA, Los Angeles, CA, USA; Maja Bucan PhD, University of Pennsylvania, Philadelphia, PA, USA; W Ted Brown MD PhD FACMG, New York State Institute for Basic Research in Developmental Disabilities, Staten Island, NY, USA; Rita M Cantor PhD, UCLA School of Medicine, Los Angeles, CA, USA; John N Constantino MD, Washington University School of Medicine, St Louis, MO, USA; T Conrad Gilliam PhD, University of Chicago, Chicago, IL, USA; Martha Herbert MD PhD, University of Texas, Houston, TX, USA; Clara Lajonchere PhD, Cure Autism Now, Los Angeles, CA, USA; David H Ledbetter PhD, Emory University, Atlanta, GA, USA; Christa Lese-Martin PhD, Emory University, Atlanta, GA, USA; Janet Miller, JD, PhD, Cure Autism Now, Los Angeles, CA, USA; Stanley F Nelson MD, UCLA School of Medicine, Los Angeles, CA, USA; Gerard D Schellenberg PhD, University of Washington, Seattle, WA, USA; Carol A Samango-Sprouse EdD, George Washington University, Washington, DC, USA; Sarah Spence MD PhD, Harvard University, Boston, MA, USA; Matthew State MD PhD, Yale University, New Haven, CT, USA; Rudolph E Tanzi PhD, Massachusetts General Hospital, Boston, MA, USA

\section{Author details}

'Department of Child and Adolescent Psychiatry, Assistance Publique-Hôpitaux de Paris (AP-HP), Groupe Hospitalier Pitié-Salpêtrière, Université Pierre et Marie Curie, 47 bd de I'Hôpital, 75013 Paris, France. ${ }^{2}$ IntegraGen, 5 rue Henri Desbruères, 91000 Évry, France. ${ }^{3}$ Center of Epileptology, Reference Center for Rare Epilepsies, AP-HP, Groupe Hospitalier Pitié-Salpêtrière, 47 bd de l'Hôpital, 75013 Paris, France. ${ }^{4}$ Department of Genetics, AP-HP, Groupe Hospitalier Pitié-Salpêtrière, Université Pierre et Marie Curie, 47 bd de I'Hôpital, 75013 Paris, France. ${ }^{5}$ Centre de Recherche de I'Institut du Cerveau et de la Moelle épinière (CR-ICM), Université Pierre et Marie Curie/Institut national de la santé et de la recherche médicale (INSERM) Unité Mixte de Recherche (UMR)
S975/Centre National de la Recherche Scientifique (CNRS) UMR 7225, Département Biotechnologies et Biothérapies, Groupe Hospitalier Pitié-Salpêtrière, 47 bd de l'Hôpital, 75013 Paris, France. ${ }^{6}$ Department of Child and Adolescent Psychiatry, Groupe Hospitalier Guillaume Régnier, Université de Rennes, 108 Avenue Du General Leclerc, 35703 Rennes, France. ${ }^{7}$ Institut des Systèmes Intelligents et Robotiques (ISIR), CNRS UMR 7222, Université Pierre et Marie Curie, 1 place Jussieu, 75005 Paris, France.

Received: 3 April 2013 Accepted: 13 September 2013

Published: 1 December 2013

\section{References}

1. Canitano R: Epilepsy in autism spectrum disorders. Eur Child Adolesc Psychiatry 2007, 16:61-66.

2. Berg AT, Plioplys S, Tuchman R: Risk and correlates of autism spectrum disorder in children with epilepsy: a community-based study. J Child Neurol 2011, 26:540-547.

3. Steffenburg S, Gillberg C, Steffenburg U: Psychiatric disorders in children and adolescents with mental retardation and active epilepsy. Arch Neurol 1996, 53:904-912.

4. Clarke DF, Roberts W, Daraksan M, Dupuis A, McCabe J, Wood H, Snead OC 3rd, Weiss SK: The prevalence of autistic spectrum disorder in children surveyed in a tertiary care epilepsy clinic. Epilepsia 2005, 46:1970-1977.

5. Matsuo M, Maeda T, Sasaki K, Ishii K, Hamasaki Y: Frequent association of autism spectrum disorder in patients with childhood onset epilepsy. Brain Dev 2010, 32:759-763.

6. Fombonne E: Epidemiology of pervasive developmental disorders. Pediatr Res 2009, 65:591-598.

7. Cohen D, Pichard N, Tordjman S, Baumann C, Burglen L, Excoffier S, Lazar G, Mazet $P$, Pinquier $C$, Verloes A, Héron D: Specific genetic disorders and autism: clinical contribution towards identification. J Autism Dev Disord 2005, 35:103-116.

8. Guillem P, Cans C, Guinchat V, Ratel M, Jouk PS: Trends, perinatal characteristics, and medical conditions in pervasive developmental disorders. Dev Med Child Neurol 2006, 48:896-900.

9. Amiet C, Gourfinkel-An I, Bouzamondo A, Tordjman S, Baulac M, Lechat P, Mottron $L$, Cohen D: Epilepsy in autism is associated with intellectual disability and gender: evidence from a meta-analysis. Biol Psychiatry 2008, 64:577-582.

10. Gillberg C, Steffenburg S, Schaumann H: Is autism more common now than ten years ago? Br J Psychiatry 1991, 158:403-409.

11. Abrahams BS, Geschwind DH: Advances in autism genetics: on the threshold of a new neurobiology. Nat Rev Genet 2008, 9:341-355.

12. Bill BR, Geschwind DH: Genetic advances in autism: heterogeneity and convergence on shared pathways. Curr Opin Genet Dev 2009, 19:271-278.

13. Muhle R, Trentacoste SV, Rapin I: The genetics of autism. Pediatrics 2004 113:e472-e486.

14. Abrahams BS, Geschwind DH: Connecting genes to brain in the autism spectrum disorders. Arch Neurol 2010, 67:395-399.

15. Betancur C: Etiological heterogeneity in autism spectrum disorders: more than 100 genetic and genomic disorders and still counting. Brain Res 2011, 1380:42-77.

16. Levinson DF, Duan J, Oh S, Wang K, Sanders AR, Shi J, Zhang N, Mowry BJ, Olincy A, Amin F, Cloninger CR, Silverman JM, Buccola NG, Byerley WF, Black DW, Kendler KS, Freedman R, Dudbridge F, Pe'er I, Hakonarson H, Bergen SE, Fanous AH, Holmans PA, Gejman PV: Copy number variants in schizophrenia: confirmation of five previous findings and new evidence for 3q29 microdeletions and VIPR2 duplications. Am J Psychiatry 2011, 168:302-316.

17. Johnson MR, Shorvon SD: Heredity in epilepsy: neurodevelopment, comorbidity, and the neurological trait. Epilepsy Behav 2011, 22:421-427.

18. Claes L, Del-Favero J, Ceulemans B, Lagae L, Van Broeckhoven C, De Jonghe $P$ : De novo mutations in the sodium-channel gene SCN1A cause severe myoclonic epilepsy of infancy. Am J Hum Genet 2001, 68:1327-1332.

19. Escayg A, MacDonald BT, Meisler MH, Baulac S, Huberfeld G, An-Gourfinkel I, Brice A, LeGuern E, Moulard B, Chaigne D, et al: Mutations of SCN1A, encoding a neuronal sodium channel, in two families with GEFS +2 . Nat Genet 2000, 24:343-345.

20. Weiss LA, Escayg A, Kearney JA, Trudeau M, MacDonald BT, Mori M, Reichert J, Buxbaum JD, Meisler MH: Sodium channels SCN1A, SCN2A and SCN3A in familial autism. Mol Psychiatry 2003, 8:186-194. 
21. Kamiya K, Kaneda M, Sugawara T, Mazaki E, Okamura N, Montal M, Makita N, Tanaka M, Fukushima K, Fujiwara T, et al: A nonsense mutation of the sodium channel gene SCN2A in a patient with intractable epilepsy and mental decline. J Neurosci 2004, 24:2690-2698.

22. Heron SE, Crossland KM, Andermann E, Phillips HA, Hall AJ, Bleasel A, Shevell M, Mercho S, Seni MH, Guiot MC, et al: Sodium-channel defects in benign familial neonatal-infantile seizures. Lancet 2002, 360:851-852

23. Bartnik M, Chun-Hui Tsai A, Xia Z, Cheung SW, Stankiewicz P: Disruption of the SCN2A and SCN3A genes in a patient with mental retardation, neurobehavioral and psychiatric abnormalities, and a history of infantile seizures. Clin Genet 2010, 24:2690-2698.

24. Holland KD, Kearney JA, Glauser TA, Buck G, Keddache M, Blankston JR, Glaaser IW, Kass RS, Meisler MH: Mutation of sodium channel SCN3A in a patient with cryptogenic pediatric partial epilepsy. Neurosci Lett 2008, 433:65-70.

25. Wallace RH, Wang DW, Singh R, Scheffer IE, George AL Jr, Phillips HA, Saar K, Reis A, Johnson EW, Sutherland GR, et al: Febrile seizures and generalized epilepsy associated with a mutation in the $\mathrm{Na}+-$ channel beta1 subunit gene SCN1B. Nat Genet 1998, 19:366-370.

26. Demos MK, Macri V, Farrell K, Nelson TN, Chapman K, Accili E, Armstrong L: A novel KCNA1 mutation associated with global delay and persistent cerebellar dysfunction. Mov Disord 2009, 24:778-782.

27. Zuberi SM, Eunson LH, Spauschus A, De Silva R, Tolmie J, Wood NW, McWilliam RC, Stephenson JB, Kullmann DM, Hanna MG: A novel mutation in the human voltage-gated potassium channel gene (Kv1.1) associates with episodic ataxia type 1 and sometimes with partial epilepsy. Brain 1999, 122(Pt 5):817-825.

28. Borgatti R, Zucca C, Cavallini A, Ferrario M, Panzeri C, Castaldo P, Soldovieri MV, Baschirotto C, Bresolin N, Dalla Bernardina B, et al: A novel mutation in KCNQ2 associated with BFNC, drug resistant epilepsy, and mental retardation. Neurology 2004, 63:57-65.

29. Biervert C, Schroeder BC, Kubisch C, Berkovic SF, Propping P, Jentsch TJ, Steinlein OK: A potassium channel mutation in neonatal human epilepsy. Science 1998, 279:403-406.

30. Charlier C, Singh NA, Ryan SG, Lewis TB, Reus BE, Leach RJ, Leppert M: A pore mutation in a novel KQT-like potassium channel gene in an idiopathic epilepsy family. Nat Genet 1998, 18:53-55

31. Du W, Bautista JF, Yang H, Diez-Sampedro A, You SA, Wang L, Kotagal P, Luders HO, Shi J, Cui J, et al: Calcium-sensitive potassium channelopathy in human epilepsy and paroxysmal movement disorder. Nat Genet 2005 37:733-738.

32. Laumonnier F, Roger S, Guerin P, Molinari F, M'Rad R, Cahard D, Belhadj A, Halayem M, Persico AM, Elia M, et al: Association of a functional deficit of the BKCa channel, a synaptic regulator of neuronal excitability, with autism and mental retardation. Am J Psychiatry 2006, 163:1622-1629.

33. Jouvenceau A, Eunson LH, Spauschus A, Ramesh V, Zuberi SM, Kullmann DM, Hanna MG: Human epilepsy associated with dysfunction of the brain P/Q-type calcium channel. Lancet 2001, 358:801-807.

34. Cossette P, Liu L, Brisebois K, Dong H, Lortie A, Vanasse M, Saint-Hilaire JM, Carmant L, Verner A, Lu WY, et al: Mutation of GABRA1 in an autosomal dominant form of juvenile myoclonic epilepsy. Nat Genet 2002, 31:184-189.

35. Baulac S, Huberfeld G, Gourfinkel-An I, Mitropoulou G, Beranger A, Prud'homme JF, Baulac M, Brice A, Bruzzone R, LeGuern E: First genetic evidence of $G A B A(A)$ receptor dysfunction in epilepsy: a mutation in the gamma2-subunit gene. Nat Genet 2001, 28:46-48.

36. Jansen FE, Sadleir LG, Harkin LA, Vadlamudi L, McMahon JM, Mulley JC, Scheffer IE, Berkovic SF: Severe myoclonic epilepsy of infancy (Dravet syndrome): recognition and diagnosis in adults. Neurology 2006, 67:2224-2226.

37. Aridon P, Marini C, Di Resta C, Brilli E, De Fusco M, Politi F, Parrini E, Manfredi I, Pisano T, Pruna D, et al: Increased sensitivity of the neuronal nicotinic receptor alpha 2 subunit causes familial epilepsy with nocturnal wandering and ictal fear. Am J Hum Genet 2006, 79:342-350.

38. Cho YW, Motamedi GK, Laufenberg I, Sohn SI, Lim JG, Lee H, Yi SD, Lee JH, Kim DK, Reba R, et al: A Korean kindred with autosomal dominant nocturnal frontal lobe epilepsy and mental retardation. Arch Neurol 2003, 60:1625-1632

39. Steinlein OK, Mulley JC, Propping P, Wallace RH, Phillips HA, Sutherland GR, Scheffer IE, Berkovic SF: A missense mutation in the neuronal nicotinic acetylcholine receptor alpha 4 subunit is associated with autosomal dominant nocturnal frontal lobe epilepsy. Nat Genet 1995, 11:201-203.
40. De Fusco M, Becchetti A, Patrignani A, Annesi G, Gambardella A, Quattrone A, Ballabio A, Wanke E, Casari G: The nicotinic receptor beta 2 subunit is mutant in nocturnal frontal lobe epilepsy. Nat Genet 2000, 26:275-276.

41. Jamain S, Quach H, Betancur C, Rastam M, Colineaux C, Gillberg IC, Soderstrom H, Giros B, Leboyer M, Gillberg C, Bourgeron T: Mutations of the $\mathrm{X}$-linked genes encoding neuroligins NLGN3 and NLGN4 are associated with autism. Nat Genet 2003, 34:27-29.

42. Laumonnier F, Bonnet-Brilhault F, Gomot M, Blanc R, David A, Moizard MP, Raynaud M, Ronce N, Lemonnier E, Calvas $P$, et al: X-linked mental retardation and autism are associated with a mutation in the NLGN4 gene, a member of the neuroligin family. Am J Hum Genet 2004, 74:552-557.

43. Pagnamenta AT, Khan H, Walker S, Gerrelli D, Wing K, Bonaglia MC, Giorda R, Berney T, Mani E, Molteni M, et al: Rare familial 16q21 microdeletions under a linkage peak implicate cadherin $8(\mathrm{CDH} 8)$ in susceptibility to autism and learning disability. J Med Genet 2011, 48:48-54.

44. Morrow EM, Yoo SY, Flavell SW, Kim TK, Lin Y, Hill RS, Mukaddes NM, Balkhy S, Gascon G, Hashmi A, et al: Identifying autism loci and genes by tracing recent shared ancestry. Science 2008, 321:218-223.

45. Dibbens LM, Tarpey PS, Hynes K, Bayly MA, Scheffer IE, Smith R, Bomar J, Sutton E, Vandeleur L, Shoubridge C, et al: X-linked protocadherin 19 mutations cause female-limited epilepsy and cognitive impairment. Nat Genet 2008, 40:776-781.

46. Kim HG, Kishikawa S, Higgins AW, Seong IS, Donovan DJ, Shen Y, Lally E, Weiss LA, Najm J, Kutsche K, et al: Disruption of neurexin 1 associated with autism spectrum disorder. Am J Hum Genet 2008, 82:199-207.

47. Kirov G, Gumus D, Chen W, Norton N, Georgieva L, Sari M, O'Donovan MC, Erdogan F, Owen MJ, Ropers HH, Ullmann R: Comparative genome hybridization suggests a role for NRXN1 and APBA2 in schizophrenia. Hum Mol Genet 2008, 17:458-465.

48. Harrison V, Connell L, Hayesmoore J, McParland J, Pike MG, Blair E: Compound heterozygous deletion of NRXN1 causing severe developmental delay with early onset epilepsy in two sisters. Am J Med Genet A 2011, 155A:2826-2831.

49. Strauss KA, Puffenberger EG, Huentelman MJ, Gottlieb S, Dobrin SE, Parod JM, Stephan DA, Morton DH: Recessive symptomatic focal epilepsy and mutant contactin-associated protein-like 2. N Engl J Med 2006, 354:1370-1377.

50. Friedman II, Vrijenhoek T, Markx S, Janssen IM, van der Vliet WA, Faas BH, Knoers NV, Cahn W, Kahn RS, Edelmann L, et al: CNTNAP2 gene dosage variation is associated with schizophrenia and epilepsy. Mol Psychiatry 2008, 13:261-266

51. Rossi E, Verri AP, Patricelli MG, Destefani V, Ricca I, Vetro A, Ciccone R, Giorda R, Toniolo D, Maraschio P, Zuffardi O: A $12 \mathrm{Mb}$ deletion at 7q33-q35 associated with autism spectrum disorders and primary amenorrhea. Eur J Med Genet 2008, 51:631-638.

52. Berkel S, Marshall CR, Weiss B, Howe J, Roeth R, Moog U, Endris V, Roberts W, Szatmari P, Pinto D, et al: Mutations in the SHANK2 synaptic scaffolding gene in autism spectrum disorder and mental retardation. Nat Genet 2010, 42:489-491.

53. Durand CM, Betancur C, Boeckers TM, Bockmann J, Chaste P, Fauchereau F Nygren G, Rastam M, Gillberg IC, Anckarsater H, et al: Mutations in the gene encoding the synaptic scaffolding protein SHANK3 are associated with autism spectrum disorders. Nat Genet 2007, 39:25-27.

54. Gauthier J, Champagne N, Lafreniere RG, Xiong L, Spiegelman D, Brustein E, Lapointe $M$, Peng H, Cote M, Noreau A, et al: De novo mutations in the gene encoding the synaptic scaffolding protein SHANK3 in patients ascertained for schizophrenia. Proc Natl Acad Sci U S A 2010, 107:7863-7868.

55. Hamdan FF, Daoud H, Piton A, Gauthier J, Dobrzeniecka S, Krebs MO, Joober R, Lacaille JC, Nadeau A, Milunsky JM, et al: De novo SYNGAP1 mutations in nonsyndromic intellectual disability and autism. Biol Psychiatry 2011, 69:898-901.

56. Hamdan FF, Gauthier J, Spiegelman D, Noreau A, Yang Y, Pellerin S, Dobrzeniecka S, Cote M, Perreau-Linck E, Carmant L, et al: Mutations in SYNGAP1 in autosomal nonsyndromic mental retardation. N Engl J Med 2009, 360:599-605.

57. Tao J, Van Esch H, Hagedorn-Greiwe M, Hoffmann K, Moser B, Raynaud M, Sperner J, Fryns JP, Schwinger E, Gecz J, et al: Mutations in the X-linked cyclin-dependent kinase-like 5 (CDKL5/STK9) gene are associated with severe neurodevelopmental retardation. Am J Hum Genet 2004, 75:1149-1154.

58. Weaving LS, Christodoulou J, Williamson SL, Friend KL, McKenzie OL, Archer H, Evans J, Clarke A, Pelka GJ, Tam PP, et al: Mutations of CDKL5 cause a severe neurodevelopmental disorder with infantile spasms and mental retardation. Am J Hum Genet 2004, 75:1079-1093. 
59. Stromme P, Mangelsdorf ME, Scheffer IE, Gecz J: Infantile spasms, dystonia, and other X-linked phenotypes caused by mutations in Aristaless related homeobox gene, ARX. Brain Dev 2002, 24:266-268.

60. Stromme P, Mangelsdorf ME, Shaw MA, Lower KM, Lewis SM, Bruyere $H$, Lutcherath V, Gedeon AK, Wallace RH, Scheffer IE, et al: Mutations in the human ortholog of Aristaless cause X-linked mental retardation and epilepsy. Nat Genet 2002, 30:441-445.

61. Vanmolkot KR, Kors EE, Hottenga JJ, Terwindt GM, Haan J, Hoefnagels WA, Black DF, Sandkuijl LA, Frants RR, Ferrari MD, van den Maagdenberg AM: Novel mutations in the $\mathrm{Na}+, \mathrm{K}+-$ ATPase pump gene ATP1A2 associated with familial hemiplegic migraine and benign familial infantile convulsions. Ann Neurol 2003, 54:360-366.

62. Vanmolkot KR, Stroink H, Koenderink JB, Kors EE, van den Heuvel JJ, van den Boogerd EH, Stam AH, Haan J, De Vries BB, Terwindt GM, et al: Severe episodic neurological deficits and permanent mental retardation in a child with a novel FHM2 ATP1A2 mutation. Ann Neurol 2006, 59:310-314.

63. Suls A, Dedeken P, Goffin K, Van Esch H, Dupont P, Cassiman D, Kempfle J, Wuttke TV, Weber $Y$, Lerche $H$, et al: Paroxysmal exercise-induced dyskinesia and epilepsy is due to mutations in SLC2A1, encoding the glucose transporter GLUT1. Brain 2008, 131:1831-1844.

64. Saitsu H, Kato M, Mizuguchi T, Hamada K, Osaka H, Tohyama J, Uruno K, Kumada S, Nishiyama K, Nishimura A, et al: De novo mutations in the gene encoding STXBP1 (MUNC18-1) cause early infantile epileptic encephalopathy. Nat Genet 2008, 40:782-788.

65. Amiet C: Autisme et épilepsie: association fortuite ou physiopathologie commune? Ecole Doctorale Cerveau, Cognition, Comportement: Université Pierre et Marie Curie; 2011.

66. Mefford HC, Sharp AJ, Baker C, Itsara A, Jiang Z, Buysse K, Huang S, Maloney VK, Crolla JA, Baralle D, et al: Recurrent rearrangements of chromosome 1q21.1 and variable pediatric phenotypes. N Engl J Med 2008, 359:1685-1699.

67. Brunetti-Pierri N, Berg JS, Scaglia F, Belmont J, Bacino CA, Sahoo T, Lalani SR, Graham B, Lee B, Shinawi M, et al: Recurrent reciprocal 1q21.1 deletions and duplications associated with microcephaly or macrocephaly and developmental and behavioral abnormalities. Nat Genet 2008, 40:1466-1471.

68. Pinto D, Pagnamenta AT, Klei L, Anney R, Merico D, Regan R, Conroy J, Magalhaes TR, Correia C, Abrahams BS, et al: Functional impact of global rare copy number variation in autism spectrum disorders. Nature 2010, 466:368-372.

69. Stewart LR, Hall AL, Kang SH, Shaw CA, Beaudet AL: High frequency of known copy number abnormalities and maternal duplication 15q11-q13 in patients with combined schizophrenia and epilepsy. BMC Med Genet 2011, 12:154.

70. Stefansson H, Rujescu D, Cichon S, Pietilainen OP, Ingason A, Steinberg S, Fossdal R, Sigurdsson E, Sigmundsson T, Buizer-Voskamp JE, et al: Large recurrent microdeletions associated with schizophrenia. Nature 2008, 455:232-236.

71. The International Schizophrenia Consortium: Rare chromosomal deletions and duplications increase risk of schizophrenia. Nature 2008, 455:237-241.

72. Kirov G, Grozeva D, Norton N, Ivanov D, Mantripragada KK, Holmans P, Craddock N, Owen MJ, O'Donovan MC: Support for the involvement of large copy number variants in the pathogenesis of schizophrenia. Hum Mol Genet 2009, 18:1497-1503.

73. Mefford HC, Muhle H, Ostertag P, von Spiczak S, Buysse K, Baker C, Franke A, Malafosse A, Genton P, Thomas P, et al: Genome-wide copy number variation in epilepsy: novel susceptibility loci in idiopathic generalized and focal epilepsies. PLoS Genet 2010, 6:e1000962.

74. Walsh T, McClellan JM, McCarthy SE, Addington AM, Pierce SB, Cooper GM Nord AS, Kusenda M, Malhotra D, Bhandari A, et al: Rare structural variants disrupt multiple genes in neurodevelopmental pathways in schizophrenia. Science 2008, 320:539-543.

75. Kirov G, Pocklington AJ, Holmans P, Ivanov D, Ikeda M, Ruderfer D, Moran J, Chambert K, Toncheva D, Georgieva L, et al: De novo CNV analysis implicates specific abnormalities of postsynaptic signalling complexes in the pathogenesis of schizophrenia. Mol Psychiatry 2011.

76. Ballif BC, Theisen A, Coppinger J, Gowans GC, Hersh JH, Madan-Khetarpal S, Schmidt KR, Tervo R, Escobar LF, Friedrich CA, et al: Expanding the clinical phenotype of the 3q29 microdeletion syndrome and characterization of the reciprocal microduplication. Mol Cytogenet 2008, 1:8.

77. Baynam G, Goldblatt J, Townshend S: A case of $3 q 29$ microdeletion with novel features and a review of cytogenetically visible terminal $3 q$ deletions. Clin Dysmorphol 2006, 15:145-148.
78. Quintero-Rivera F, Sharifi-Hannauer P, Martinez-Agosto JA: Autistic and psychiatric findings associated with the $3 q 29$ microdeletion syndrome: case report and review. Am J Med Genet A 2010, 152A:2459-2467.

79. Willatt L, Cox J, Barber J, Cabanas ED, Collins A, Donnai D, FitzPatrick DR, Maher E, Martin H, Parnau J, et al: 3q29 microdeletion syndrome: clinical and molecular characterization of a new syndrome. Am J Hum Genet 2005, 77:154-160.

80. Mulle JG, Dodd AF, McGrath JA, Wolyniec PS, Mitchell AA, Shetty AC, Sobreira NL, Valle D, Rudd MK, Satten G, et al: Microdeletions of 3q29 confer high risk for schizophrenia. Am J Hum Genet 2010, 87:229-236.

81. Magri C, Sacchetti E, Traversa M, Valsecchi P, Gardella R, Bonvicini C, Minell A, Gennarelli M, Barlati S: New copy number variations in schizophrenia. PLoS One 2010, 5:e13422.

82. Klein-Tasman BP, Phillips KD, Lord C, Mervis CB, Gallo FJ: Overlap with the autism spectrum in young children with Williams syndrome. J Dev Behav Pediatr 2009, 30:289-299.

83. Sanders SJ, Ercan-Sencicek AG, Hus V, Luo R, Murtha MT, Moreno-De-Luca D, Chu SH, Moreau MP, Gupta AR, Thomson SA, et al: Multiple Recurrent De Novo CNVs, Including Duplications of the 7q11.23 Williams Syndrome Region, Are Strongly Associated with Autism. Neuron 2011, 70:863-885.

84. Depienne C, Heron D, Betancur C, Benyahia B, Trouillard O, Bouteiller D, Verloes A, LeGuern E, Leboyer M, Brice A: Autism, language delay and mental retardation in a patient with 7q11 duplication. J Med Genet 2007, 44:452-458

85. Berg JS, Brunetti-Pierri N, Peters SU, Kang SH, Fong CT, Salamone J, Freedenberg D, Hannig VL, Prock LA, Miller DT, et al: Speech delay and autism spectrum behaviors are frequently associated with duplication of the 7q11.23 WilliamsBeuren syndrome region. Genet Med 2007, 9:427-441.

86. Kirchhoff M, Bisgaard AM, Bryndorf T, Gerdes T: MLPA analysis for a panel of syndromes with mental retardation reveals imbalances in $5.8 \%$ of patients with mental retardation and dysmorphic features, including duplications of the Sotos syndrome and Williams-Beuren syndrome regions. Eur J Med Genet 2007, 50:33-42.

87. Qiao Y, Riendeau N, Koochek M, Liu X, Harvard C, Hildebrand MJ, Holden JJ, Rajcan-Separovic E, Lewis ME: Phenomic determinants of genomic variation in autism spectrum disorders. J Med Genet 2009, 46:680-688.

88. Van der Aa N, Rooms L, Vandeweyer G, van den Ende J, Reyniers E, Fichera M, Romano C, Delle Chiaie B, Mortier G, Menten B, et al: Fourteen new cases contribute to the characterization of the $7 q 11.23$ microduplication syndrome. Eur J Med Genet 2009, 52:94-100.

89. Lincoln AJ, Searcy YM, Jones W, Lord C: Social interaction behaviors discriminate young children with autism and Williams syndrome. J Am Acad Child Adolesc Psychiatry 2007, 46:323-331.

90. Mefford HC, Cooper GM, Zerr T, Smith JD, Baker C, Shafer N, Thorland EC, Skinner C, Schwartz CE, Nickerson DA, Eichler EE: A method for rapid, targeted CNV genotyping identifies rare variants associated with neurocognitive disease. Genome Res 2009, 19:1579-1585.

91. Depienne C, Moreno-De-Luca D, Heron D, Bouteiller D, Gennetier A, Delorme R, Chaste P, Siffroi JP, Chantot-Bastaraud S, Benyahia B, et al: Screening for genomic rearrangements and methylation abnormalities of the 15q11-q13 region in autism spectrum disorders. Biol Psychiatry 2009, 66:349-359.

92. de Kovel CG, Trucks H, Helbig I, Mefford HC, Baker C, Leu C, Kluck C, Muhle $H$, von Spiczak S, Ostertag P, et al: Recurrent microdeletions at $15 q 11.2$ and 16p13.11 predispose to idiopathic generalized epilepsies. Brain 2010, $133: 23-32$.

93. Helbig I, Mefford HC, Sharp AJ, Guipponi M, Fichera M, Franke A, Muhle H, de Kovel C, Baker C, von Spiczak S, et al: 15q13.3 microdeletions increase risk of idiopathic generalized epilepsy. Nat Genet 2009, 41:160-162.

94. Dibbens LM, Mullen S, Helbig I, Mefford HC, Bayly MA, Bellows S, Leu C, Trucks H, Obermeier T, Wittig M, et al: Familial and sporadic 15q13.3 microdeletions in idiopathic generalized epilepsy: precedent for disorders with complex inheritance. Hum Mol Genet 2009, 18:3626-3631

95. Ben-Shachar S, Lanpher B, German JR, Qasaymeh M, Potocki L, Nagamani SC, Franco LM, Malphrus A, Bottenfield GW, Spence JE, et al: Microdeletion 15q13.3: a locus with incomplete penetrance for autism, mental retardation, and psychiatric disorders. J Med Genet 2009, 46:382-388.

96. Masurel-Paulet A, Andrieux J, Callier P, Cuisset JM, Le Caignec C, Holder M, Thauvin-Robinet C, Doray B, Flori E, Alex-Cordier MP, et al: Delineation of 15q13.3 microdeletions. Clin Genet 2010, 78:149-161. 
97. Miller DT, Shen Y, Weiss LA, Korn J, Anselm I, Bridgemohan C, Cox GF, Dickinson H, Gentile J, Harris DJ, et al: Microdeletion/duplication at $15 q 13.2 q 13.3$ among individuals with features of autism and other neuropsychiatric disorders. J Med Genet 2009, 46:242-248.

98. van Bon BW, Mefford HC, Menten B, Koolen DA, Sharp AJ, Nillesen WM, Innis JW, de Ravel TJ, Mercer CL, Fichera M, et al: Further delineation of the 15q13 microdeletion and duplication syndromes: a clinical spectrum varying from non-pathogenic to a severe outcome. J Med Genet 2009, 46:511-523.

99. Sharp AJ, Mefford HC, Li K, Baker C, Skinner C, Stevenson RE, Schroer RJ, Novara F, De Gregori M, Ciccone R, et al: A recurrent $15 q 13.3$ microdeletion syndrome associated with mental retardation and seizures. Nat Genet 2008, 40:322-328.

100. Shinawi M, Schaaf CP, Bhatt SS, Xia Z, Patel A, Cheung SW, Lanpher B, Nag $\mathrm{S}$, Herding HS, Nevinny-Stickel $\mathrm{C}$, et al: A small recurrent deletion within $15 q 13.3$ is associated with a range of neurodevelopmental phenotypes. Nat Genet 2009, 41:1269-1271.

101. Marshall CR, Noor A, Vincent JB, Lionel AC, Feuk L, Skaug J, Shago M, Moessner R, Pinto D, Ren $Y$, et al: Structural variation of chromosomes in autism spectrum disorder. Am J Hum Genet 2008, 82:477-488.

102. Kumar RA, KaraMohamed S, Sudi J, Conrad DF, Brune C, Badner JA, Gilliam TC, Nowak NJ, Cook EH Jr, Dobyns WB, Christian SL: Recurrent 16p11.2 microdeletions in autism. Hum Mol Genet 2008, 17:628-638.

103. McCarthy SE, Makarov V, Kirov G, Addington AM, McClellan J, Yoon S, Perkins DO, Dickel DE, Kusenda M, Krastoshevsky O, et al: Microduplications of 16p11.2 are associated with schizophrenia. Nat Genet 2009, 41:1223-1227.

104. Fernandez BA, Roberts W, Chung B, Weksberg R, Meyn S, Szatmari P, Joseph-George AM, Mackay S, Whitten K, Noble B, et al: Phenotypic spectrum associated with de novo and inherited deletions and duplications at 16p11.2 in individuals ascertained for diagnosis of autism spectrum disorder. J Med Genet 2010, 47:195-203.

105. Rosenfeld JA, Ballif BC, Torchia BS, Sahoo T, Ravnan JB, Schultz R, Lamb A, Bejjani BA, Shaffer LG: Copy number variations associated with autism spectrum disorders contribute to a spectrum of neurodevelopmental disorders. Genet Med 2010, 12:694-702.

106. Weiss LA, Shen Y, Korn JM, Arking DE, Miller DT, Fossdal R, Saemundsen E, Stefansson H, Ferreira MA, Green T, et al: Association between microdeletion and microduplication at 16p11.2 and autism. N Engl J Med 2008, 358:667-675

107. Shinawi M, Liu P, Kang SH, Shen J, Belmont JW, Scott DA, Probst FJ, Craigen WJ, Graham BH, Pursley A, et al: Recurrent reciprocal 16p11.2 rearrangements associated with global developmental delay, behavioural problems, dysmorphism, epilepsy, and abnormal head size. J Med Genet 2010, 47:332-341.

108. Sebat J, Lakshmi B, Malhotra D, Troge J, Lese-Martin C, Walsh T, Yamrom B, Yoon S, Krasnitz A, Kendall J, Leotta A, Pai D, Zhang R, Lee YH, Hicks J, Spence SJ, Lee AT, Puura K, Lehtimäki T, Ledbetter D, Gregersen PK, Bregman J, Sutcliffe JS, Jobanputra V, Chung W, Warburton D, King MC, Skuse D, Geschwind DH, Gilliam TC, et al: Strong association of de novo copy number mutations with autism. Science 2007, 316:445-449.

109. Bijlsma EK, Gijsbers AC, Schuurs-Hoeijmakers JH, van Haeringen A, van de Putte DE F, Anderlid BM, Lundin J, Lapunzina P, Perez Jurado LA, Delle Chiaie $B$, et al: Extending the phenotype of recurrent rearrangements of 16p11.2: deletions in mentally retarded patients without autism and in normal individuals. Eur J Med Genet 2009, 52:77-87.

110. Hanson E, Nasir RH, Fong A, Lian A, Hundley R, Shen Y, Wu BL, Holm IA, Miller DT: Cognitive and behavioral characterization of $16 \mathrm{p} 11.2$ deletion syndrome. J Dev Behav Pediatr 2010, 31:649-657.

111. Heinzen EL, Radtke RA, Urban TJ, Cavalleri GL, Depondt C, Need AC, Walley NM, Nicoletti P, Ge D, Catarino CB, et al: Rare deletions at 16p13.11 predispose to a diverse spectrum of sporadic epilepsy syndromes. Am J Hum Genet 2010, 86:707-718.

112. Ullmann R, Turner G, Kirchhoff M, Chen W, Tonge B, Rosenberg C, Field M, Vianna-Morgante AM, Christie L, Krepischi-Santos AC, et al: Array CGH identifies reciprocal 16p13.1 duplications and deletions that predispose to autism and/or mental retardation. Hum Mutat 2007, 28:674-682

113. Ingason A, Rujescu D, Cichon S, Sigurdsson E, Sigmundsson T, Pietilainen OP, Buizer-Voskamp JE, Strengman E, Francks C, Muglia P, et al: Copy number variations of chromosome 16p13.1 region associated with schizophrenia. Mol Psychiatry 2011, 16:17-25.

114. Hannes FD, Sharp AJ, Mefford HC, de Ravel T, Ruivenkamp CA, Breuning $\mathrm{MH}$, Fryns JP, Devriendt K, Van Buggenhout G, Vogels A, et al: Recurrent reciprocal deletions and duplications of 16p13.11: the deletion is a risk factor for MR/MCA while the duplication may be a rare benign variant. $J$ Med Genet 2009, 46:223-232.

115. Nagamani SC, Erez A, Shen J, Li C, Roeder E, Cox S, Karaviti L, Pearson M, Kang $\mathrm{SH}$, Sahoo T, et al: Clinical spectrum associated with recurrent genomic rearrangements in chromosome 17q12. Eur J Hum Genet 2010, 18:278-284.

116. Loirat C, Bellanne-Chantelot C, Husson I, Deschenes G, Guigonis V, Chabane $\mathrm{N}$ : Autism in three patients with cystic or hyperechogenic kidneys and chromosome 17q12 deletion. Nephrol Dial Transplant 2010, 25:3430-3433.

117. Moreno-De-Luca D, Mulle JG, Kaminsky EB, Sanders SJ, Myers SM, Adam MP, Pakula AT, Eisenhauer NJ, Uhas K, Weik L, et al: Deletion $17 q 12$ is a recurrent copy number variant that confers high risk of autism and schizophrenia. Am J Hum Genet 2010, 87:618-630.

118. Fine SE, Weissman A, Gerdes M, Pinto-Martin J, Zackai EH, McDonaldMcGinn DM, Emanuel BS: Autism spectrum disorders and symptoms in children with molecularly confirmed 22q11.2 deletion syndrome. J Autism Dev Disord 2005, 35:461-470.

119. Niklasson L, Rasmussen P, Oskarsdottir S, Gillberg C: Autism, ADHD, mental retardation and behavior problems in 100 individuals with $22 q 11$ deletion syndrome. Res Dev Disabil 2009, 30:763-773.

120. Wong M, Ess KC, Uhlmann EJ, Jansen LA, Li W, Crino PB, Mennerick S, Yamada KA, Gutmann DH: Impaired glial glutamate transport in a mouse tuberous sclerosis epilepsy model. Ann Neurol 2003, 54:251-256.

121. Newschaffer CJ, Croen LA, Daniels J, Giarelli E, Grether JK, Levy SE, Mandell DS, Miller LA, Pinto-Martin J, Reaven J, Reynolds AM, Rice CE, Schendel D, Windham GC: The epidemiology of autism spectrum disorders. Annu Rev Public Health 2007, 28:235-258

122. Guinchat V, Thorsen P, Laurent C, Cans C, Bodeau N, Cohen D: Pre-, peri-, and neonatal risk factors for autism. Acta Obstet Gynecol Scand 2012, 91:287-300.

123. Carayol J, Schellenberg GD, Dombroski B, Genin E, Rousseau F, Dawson G: Autism risk assessment in siblings of affected children using sex-specific genetic scores. Mol Autism 2011, 2:17

124. Carayol J, Schellenberg GD, Tores F, Hager J, Ziegler A, Dawson G: Assessing the impact of a combined analysis of four common low-risk genetic variants on autism risk. Mol Autism 2010, 1:4.

125. Ritvo ER, Mason-Brothers A, Freeman BJ, Pingree C, Jenson WR, McMahon WM, Petersen PB, Jorde LB, Mo A, Ritvo A: The UCLA-University of Utah epidemiologic survey of autism: the etiologic role of rare diseases. Am J Psychiatry 1990, 147:1614-1621.

126. Banach R, Thompson A, Szatmari P, Goldberg J, Tuff L, Zwaigenbaum L, Mahoney W: Brief report: relationship between non-verbal IQ and gender in autism. J Autism Dev Disord 2009, 39:188-193.

127. Lord C, Rutter M, Le Couteur A: Autism Diagnostic Interview-Revised: a revised version of a diagnostic interview for caregivers of individuals with possible pervasive developmental disorders. J Autism Dev Disord 1994, 24:659-685.

128. Geschwind DH, Sowinski J, Lord C, Iversen P, Shestack J, Jones P, Ducat L, Spence SJ: The autism genetic resource exchange: a resource for the study of autism and related neuropsychiatric conditions. Am J Hum Genet 2001, 69:463-466.

129. Wang K, Zhang H, Ma D, Bucan M, Glessner JT, Abrahams BS, Salyakina D, Imielinski M, Bradfield JP, Sleiman PM, Kim CE, Hou C, Frackelton E, Chiavacci R, Takahashi N, Sakurai T, Rappaport E, Lajonchere CM, Munson J, Estes A, Korvatska O, Piven J, Sonnenblick LI, Alvarez Retuerto Al, Herman El, Dong H, Hutman T, Sigman M, Ozonoff S, Klin A, et al: Common genetic variants on 5p14.1 associate with autism spectrum disorders. Nature 2009, 459:528-533.

130. Weiss LA, Arking DE, Daly MJ, Chakravarti A: A genome-wide linkage and association scan reveals novel loci for autism. Nature 2009, 461:802-808.

131. Raven J, Raven JC, Court JH: Section 2: The Coloured Progressive Matrices. In Manual for Raven's Progressive Matrices and Vocabulary Scales. San Antonio, TX: Harcourt Assessment; 1998.

132. Duncan J, Seitz RJ, Kolodny J, Bor D, Herzog H, Ahmed A, Newell FN, Emslie $\mathrm{H}$ : A neural basis for general intelligence. Science 2000, 289:457-460.

133. Sparrow S, Balla D, Cicchetti D: Vineland Adaptative Behavior Scales. Circle Pines, MN: American Guidance Service; 1984

134. Sparrow SS, Cicchetti DV, Balla DA: Vineland Adaptative Behavior Scales. 2nd edition. Circle Pines, MN: American Guidance Service; 2005.

135. Amiet C, Gourfinkel-An I, Laurent C, Carayol J, Genin B, Leguern E, Tordjman $\mathrm{S}$, Cohen D: Epilepsy in simplex autism pedigrees is much lower than the rate in multiplex autism pedigrees. Biol Psychiatry 2013, 74:e3-e4. 
136. Guerrini R: Epilepsy in children. Lancet 2006, 367:499-524.

137. Tuchman R, Rapin I: Epilepsy in autism. Lancet Neurol 2002, 1:352-358.

138. Spiker D, Lotspeich LJ, Dimiceli S, Szatmari P, Myers RM, Risch N: Birth order effects on nonverbal IQ scores in autism multiplex families. J Autism Dev Disord 2001, 31:449-460.

139. Miles JH, McCathren RB, Stichter J, Shinawi M: Autism Spectrum Disorders. In GeneReviews (Internet). Edited by Pagon RA, Adam MP, Bird TD, Dolan CR, Fong CT, Stephens K. Seattle, WA: University of Washington; 1993-2003.

140. Casanova MF, Buxhoeveden D, Gomez J: Disruption in the inhibitory architecture of the cell minicolumn: implications for autisim. Neuroscientist 2003, 9:496-507.

141. Casanova MF, El-Baz A, Vanbogaert E, Narahari P, Switala A: A topographic study of minicolumnar core width by lamina comparison between autistic subjects and controls: possible minicolumnar disruption due to an anatomical element in-common to multiple laminae. Brain Pathol 2010, 20:451-458.

142. Nass R, Gross A, Wisoff J, Devinsky O: Outcome of multiple subpial transections for autistic epileptiform regression. Pediatr Neurol 1999, 21:464-470

143. Brooks-Kayal A: Epilepsy and autism spectrum disorders: are there common developmental mechanisms? Brain Dev 2010, 32:731-738

144. Brooks-Kayal A: Molecular mechanisms of cognitive and behavioral comorbidities of epilepsy in children. Epilepsia 2011, 52(Suppl 1):13-20.

145. Saemundsen E, Ludvigsson P, Hilmarsdottir I, Rafnsson V: Autism spectrum disorders in children with seizures in the first year of life - a populationbased study. Epilepsia 2007, 48:1724-1730.

146. Saemundsen E, Ludvigsson P, Rafnsson V: Risk of autism spectrum disorders after infantile spasms: a population-based study nested in a cohort with seizures in the first year of life. Epilepsia 2008, 49:1865-1870.

147. Saemundsen E, Ludvigsson P, Rafnsson V: Autism spectrum disorders in children with a history of infantile spasms: a population-based study. J Child Neurol 2007, 22:1102-1107.

148. Greer PL, Hanayama R, Bloodgood BL, Mardinly AR, Lipton DM, Flavell SW, Kim TK, Griffith EC, Waldon Z, Maehr R, Ploegh HL, Chowdhury S, Worley PF, Steen J, Greenberg ME: The Angelman syndrome protein Ube3A regulates synapse development by ubiquitinating arc. Cell 2010, 140:704-716.

149. Bassell GJ, Warren ST: Fragile X syndrome: loss of local mRNA regulation alters synaptic development and function. Neuron 2008, 60:201-214.

150. Gonzales ML, LaSalle JM: The role of MeCP2 in brain development and neurodevelopmental disorders. Curr Psychiatry Rep 2010, 12:127-134

151. White R, Hua Y, Scheithauer B, Lynch DR, Henske EP, Crino PB: Selective alterations in glutamate and GABA receptor subunit mRNA expression in dysplastic neurons and giant cells of cortical tubers. Ann Neurol 2001, 49:67-78.

152. Crespi BJ, Crofts HJ: Association testing of copy number variants in schizophrenia and autism spectrum disorders. J Neurodev Disord 2012, 4:15.

153. Sullivan PF, Daly MJ, O'Donovan M: Genetic architectures of psychiatric disorders: the emerging picture and its implications. Nat Rev Genet 2012, 13:537-551.

154. Dawson M, Soulieres I, Gernsbacher MA, Mottron L: The level and nature of autistic intelligence. Psychol Sci 2007, 18:657-662.

155. Kanne SM, Gerber AJ, Quirmbach LM, Sparrow SS, Cicchetti DV, Saulnier CA: The role of adaptive behavior in autism spectrum disorders: implications for functional outcome. J Autism Dev Disord 2011, 41:1007-1018.

doi:10.1186/2040-2392-4-47

Cite this article as: Amiet et al: Does epilepsy in multiplex autism pedigrees define a different subgroup in terms of clinical characteristics and genetic risk? Molecular Autism 2013 4:47.

\section{Submit your next manuscript to BioMed Central and take full advantage of:}

- Convenient online submission

- Thorough peer review

- No space constraints or color figure charges

- Immediate publication on acceptance

- Inclusion in PubMed, CAS, Scopus and Google Scholar

- Research which is freely available for redistribution

Submit your manuscript at www.biomedcentral.com/submit
Ciomed Central 